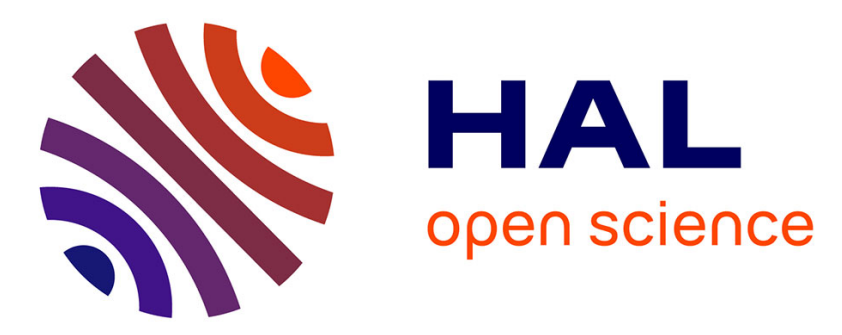

\title{
Bioaccumulation and trophic transfer of mercury in striped bass () and tautog () from the Narragansett Bay (Rhode Island, USA)
}

Maria N. Piraino, David L. Taylor

\section{- To cite this version:}

Maria N. Piraino, David L. Taylor. Bioaccumulation and trophic transfer of mercury in striped bass () and tautog () from the Narragansett Bay (Rhode Island, USA). Marine Environmental Research, 2009, 67 (3), pp.117. 10.1016/j.marenvres.2008.12.006 . hal-00563065

\section{HAL Id: hal-00563065 https://hal.science/hal-00563065}

Submitted on 4 Feb 2011

HAL is a multi-disciplinary open access archive for the deposit and dissemination of scientific research documents, whether they are published or not. The documents may come from teaching and research institutions in France or abroad, or from public or private research centers.
L'archive ouverte pluridisciplinaire HAL, est destinée au dépôt et à la diffusion de documents scientifiques de niveau recherche, publiés ou non, émanant des établissements d'enseignement et de recherche français ou étrangers, des laboratoires publics ou privés. 


\section{Accepted Manuscript}

Bioaccumulation and trophic transfer of mercury in striped bass (Morone saxatilis) and tautog (Tautoga onitis) from the Narragansett Bay (Rhode Island, USA)

Maria N. Piraino, David L. Taylor

PII:

S0141-1136(08)00250-X

DOI: 10.1016/j.marenvres.2008.12.006

Reference: MERE 3307

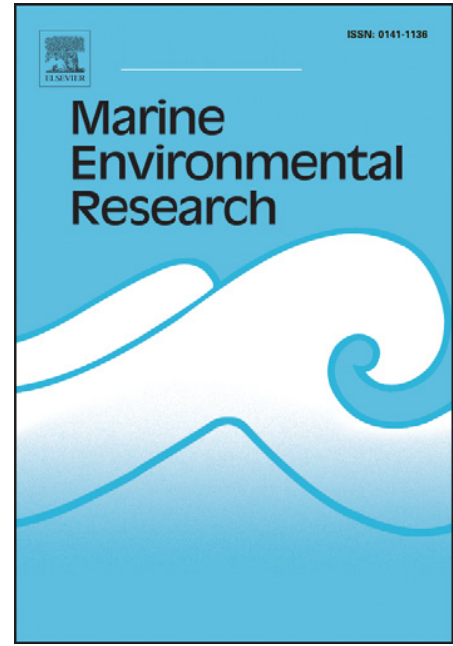

To appear in:

Marine Environmental Research

Received Date:

18 September 2008

Revised Date:

9 December 2008

Accepted Date:

12 December 2008

Please cite this article as: Piraino, M.N., Taylor, D.L., Bioaccumulation and trophic transfer of mercury in striped bass (Morone saxatilis) and tautog (Tautoga onitis) from the Narragansett Bay (Rhode Island, USA), Marine Environmental Research (2008), doi: 10.1016/j.marenvres.2008.12.006

This is a PDF file of an unedited manuscript that has been accepted for publication. As a service to our customers we are providing this early version of the manuscript. The manuscript will undergo copyediting, typesetting, and review of the resulting proof before it is published in its final form. Please note that during the production process errors may be discovered which could affect the content, and all legal disclaimers that apply to the journal pertain. 
1 Bioaccumulation and trophic transfer of mercury in striped bass (Morone saxatilis) and tautog

2 (Tautoga onitis) from the Narragansett Bay (Rhode Island, USA)

3

4 Running head: Mercury in striped bass and tautog

5

6 Key words: bioaccumulation, food web, mercury, Morone saxatilis, stable isotope, striped bass,

7 tautog, Tautoga onitis, trophic transfer

8

9 Maria N. Piraino, David L. Taylor*

10

11 Roger Williams University, Department of Marine Biology, One Old Ferry Road, Bristol, RI

1202809 , USA

13

$14 *$ corresponding author:

15 Telephone: (401) 254-3759

16 Fax: (401) 254-3310

17 E-mail: dtaylor@rwu.edu 
ABSTRACT

20 We examined the bioaccumulation and trophic transfer of mercury in two marine finfish species,

21 striped bass (Morone saxatilis) and tautog (Tautoga onitis), collected from the Narragansett Bay

22 (Rhode Island, USA). For each of these target fish, white muscle tissue was analyzed for total

23 mercury $(\mathrm{Hg})$ and results were evaluated relative to fish age, body size, and $\mathrm{Hg}$ content of

24 preferred prey. Dietary and stable isotope analysis was also used to elucidate the effect of

25 trophic processes on $\mathrm{Hg}$ concentrations in fish. The $\mathrm{Hg}$ content of muscle tissue was positively

26 correlated with fish age and length for both species, although striped bass accumulated $\mathrm{Hg}$ faster

27 than tautog. Accelerated $\mathrm{Hg}$ bioaccumulation in striped bass is consistent with its high trophic

28 level (trophic level = 4.07) and $\mathrm{Hg}$-enriched prey (forage fish and macrocrustaceans; mean $\mathrm{Hg}$

29 content $=0.03 \mathrm{mg} \mathrm{Hg} \cdot \mathrm{kg}$ wet $\mathrm{wt}^{-1}$ ). In contrast, tautog maintain a lower trophic status (trophic

30 level = 3.51) and consume prey with lower Hg levels (mussels and crabs; mean Hg content =

$310.02 \mathrm{mg} \mathrm{Hg} \cdot \mathrm{kg}$ wet $\mathrm{wt}^{-1}$ ). Despite differences in $\mathrm{Hg}$ bioaccumulation between target fish, the

32 mean $\mathrm{Hg}$ concentration of tautog exceeded levels in striped bass $(0.24$ and $0.16 \mathrm{mg} \mathrm{Hg} \cdot \mathrm{kg}$ wet

$33 \mathrm{wt}^{-1}$, respectively) due to a disparity in age-at-catch between sampled groups (mean age of tautog

34 and bass $=11.3$ and $4.3 \mathrm{yr}$, respectively). Taking into account legal minimum catch lengths

35 further revealed that $75.0 \%$ of legal-size striped bass $(>70.2 \mathrm{~cm}$ TL; $n=4)$ and $44.8 \%$ of tautog

36 (>40.6 cm TL; $n=29)$ had $\mathrm{Hg}$ levels beyond the U.S. EPA regulatory threshold of $0.3 \mathrm{mg} \mathrm{Hg}$.

$37 \mathrm{~kg}$ wet $\mathrm{wt}^{-1}$. Moreover, Hg-length relationships suggest that each target fish meets this threshold

38 near their minimum legal catch length. Our findings reiterate the value of species ecology to

39 improve predictions of fish $\mathrm{Hg}$ and permit better management of human contamination by this

40 important dietary source. 


\section{Introduction}

Methylmercury $(\mathrm{MeHg})$ is widely recognized as one of the most widespread and toxic

44 environmental contaminants affecting human health. For example, $\mathrm{MeHg}$ exposure has been

45 linked to neurological and cardiovascular disorders, immune deficiencies, and reproductive

46 deficits in humans (Moszcynski et al., 1995; Salonen et al., 1995; Grandjean et al., 1997;

47 Sorensen et al., 1999). Dietary uptake of contaminated fish and shellfish is the most important

48 mechanism by which humans are exposed to MeHg (Fitzgerald and Clarkson, 1991; U.S. EPA,

49 1997; Hightower and Moore, 2003), and MeHg constitutes the majority of total mercury (Hg) in

50 fish muscle tissue (>95\%; Grieb et al., 1990; Bloom, 1992).

51 The uptake and accumulation of $\mathrm{MeHg}$ in aquatic food webs is affected by several

52 biological and environmental variables (Weiner et al., 2003). The main biotic factors

53 contributing to the $\mathrm{MeHg}$ burden in fish are age, body size, dietary preference, and trophic

54 position, such that $\mathrm{MeHg}$ bioaccumulation and magnification increases in larger/older fish and

55 those feeding at higher trophic levels (Weiner et al., 2003). To this end, understanding the

56 human risk to $\mathrm{MeHg}$ exposure requires insight into: (1) the trophic transfer of contaminants

57 through biotic receptors, including fish, and (2) the variability in fish $\mathrm{MeHg}$ concentrations as a

58 function of life history (e.g., ontogenetic shifts in diet and habitat use, somatic growth, and

59 longevity).

Visual estimates of a predator's stomach contents have traditionally been used to

61 elucidate trophic relationships in aquatic communities. While providing valuable information on

62 diet composition, stomach content analysis is limited because it only reflects immediate feeding

63 activity. Conversely, stable isotope analysis is routinely used to quantify the relative trophic 
64 position of a species as a function of its time-integrated diet history (Michener and Schell, 1994).

65 For example, nitrogen isotopic signatures $\left({ }^{15} \mathrm{~N} /{ }^{14} \mathrm{~N}\right)$ are effective at quantifying the trophic

66 position of an organism because enrichment of the heavier isotope $\left({ }^{15} \mathrm{~N}\right)$ occurs incrementally

67 across trophic levels at a constant rate (approx. 3-4\%o; Michener and Schell, 1994). Conversely,

68 carbon isotopic signatures $\left({ }^{13} \mathrm{C} /{ }^{12} \mathrm{C}\right)$ are consistent across trophic levels $(<1 \%$ o change between

69 primary producer and consumer; Fry and Sherr, 1984), but are valuable biomarkers for

70 identifying different sources of primary production (e.g., salt marsh grasses, macroalgae, benthic

71 microalgae, and phytoplankton) (Peterson and Howarth, 1987), and therefore are effective at

72 distinguishing between benthic and pelagic trophic linkages (France, 1995). Moreover, recent

73 studies have utilized stable isotope techniques to determine patterns of trophic transfer of

74 contaminants in food webs, yet the majority of this research has focused on freshwater systems

75 (Jarman et al., 1996; Bowles et al., 2001; Power et al., 2002; Bank et al., 2007; Cai et al., 2007).

76 The purpose of this study was to examine the bioaccumulation and trophic transfer of

77 total mercury $(\mathrm{Hg})$ in striped bass (Morone saxatilis) and tautog (Tautoga onitis): two species of

78 marine fish that support lucrative recreational and, to a lesser extent, commercial fisheries along

79 the northeastern United States. Striped bass and tautog were collected from the Narragansett

80 Bay (Rhode Island, USA), and therefore this study represents a comprehensive analysis of $\mathrm{Hg}$

81 contamination at relatively small spatial scales $\left(<400 \mathrm{~km}^{2}\right)$. Furthermore, observed patterns of

$82 \mathrm{Hg}$ concentration in striped bass and tautog were analyzed relative to the individual's age and

83 body size. Conventional dietary analyses (i.e., visual observation of stomach contents) were also

84 coupled with nitrogen and carbon stable isotope analyses to define key trophic pathways in the

85 estuarine system and quantify the transfer of $\mathrm{Hg}$ contaminants in the food web. 


\section{Materials and methods}

\subsection{Target species}

Striped bass are an estuarine-dependent species with a geographic distribution ranging from the Gulf of St. Lawrence to Florida (Collette and Klein-MacPhee, 2002). As obligate users of estuarine systems (Able, 2005), striped bass exhibit large plasticity in migration strategies that range from local seasonal movements within estuaries to extensive coastal migrations (Secor and Piccoli, 2007). Striped bass of various life history stages utilize multiple habitat-types, which are governed by the availability of preferred food resources, e.g., small forage fish and macrocrustaceans (Harding and Mann, 2003; Nelson et al., 2003, 2006). Moreover, somatic growth rates of striped bass are consistent with other temperate, long-lived fishes $(\sim 20-30 \mathrm{yr}$; Secor et al., 1995; Secor, 2000; Collette and Klein-MacPhee, 2002), but growth rates of striped bass demonstrate significant latitudinal differences (Welsh et al., 2003).

Tautog are a temperate wrasse distributed along the northwestern Atlantic coast extending from Nova Scotia to South Carolina, with peak concentrations occurring in coastal regions from Cape Cod to the Chesapeake Bay (Collette and Klein-MacPhee, 2002). In contrast to striped bass, tautog exhibit strong site fidelity (Olla et al., 1979; Able and Fahay, 1998) and only limited seasonal migrations that are attributed to estuarine residency during spring spawning events and the subsequent migration to nearshore wintering habitats (Olla et al., 1974; Briggs, 1977). The diet of tautog consists of epibenthic and encrusting invertebrates (e.g., brachyuran crabs and bivalves; Steimle et al., 2000), and the longevity of this slow-growing fish exceeds 30 yr (Cooper, 1967; Steimle and Shaheen, 1999). 
111 2.2. Sample collection, processing, and preservation

Striped bass, tautog, and "bioavailable" prey were collected from the Narragansett Bay in

1142006 and 2007 using bottom trawls, seines, fish traps, and hook \& line (Fig. 1). "Bioavailable"

115 prey are defined as small forage fish and invertebrates that were captured in the field and

116 represent common food items of striped bass and tautog (Steimle et al., 2000; Nelson et al.,

117 2003, 2006), i.e., river herring (Alosa spp.), bay anchovy (Anchoa mitchilli), Atlantic menhaden

118 (Brevoortia tyrannus), scup (Stenotomus chrysops), green crab (Carcinus maenas), black-finger

119 mud crab (Panopeus herbstii), sand shrimp (Crangon septemspinosa), and blue mussel (Mytilus

120 edulis). For a complete description of gear specifications, collection locations, and sample

121 frequency, refer to the sampling procedures identified in Lynch (2000) and Collie et al. (2008).

122 Fish and invertebrates captured in the field were immediately placed on ice for

123 transportation and frozen at $-4^{\circ} \mathrm{C}$ after returning to the laboratory. Individuals were then

124 partially thawed and measured for wet weight (g) and total length (TL cm; fish and shrimp),

125 carapace width (CW cm; crabs), or shell height ( $\mathrm{SH} \mathrm{cm}$; blue mussels) (Tables 1 and 2).

126 Bioavailable prey were subsequently processed and analyzed as whole-body samples, with the

127 exception of mussels that had their shells removed. For striped bass and tautog, $\sim 2.5 \mathrm{~g}$ wet

128 weight of white muscle tissue (with scales and skin removed) was excised from the dorsal region

129 above the operculum using a stainless-steel scalpel $\left(\mathrm{D}_{0}=1\right.$ biopsy per left and right side of the

130 fish; Fig. 2A). To ensure that the total mercury concentration of this biopsy was indicative of the

131 whole-body filet, a sub-sample of bass and tautog ( $n=18$ and 14, respectively) had additional

132 biopsies excised from the dorsal and lateral tissue along the anterior-posterior axis $\left(\mathrm{D}_{1-3}\right.$ and $\mathrm{L}_{1-3}$; 
1336 biopsies per left and right side of the fish; Fig. 2A). The stomachs of bass and tautog were also

134 removed, and the contents were examined. The "recovered" prey items from dissected stomachs

135 were identified to the lowest practical taxon, and where possible, measured for wet weight (g)

136 and TL (cm; fish and shrimp) or CW (cm; crabs). For final preservation, all samples were

137 freeze-dried for $48 \mathrm{hr}$ (Labconco FreeZone 4.5 L Benchtop Freeze-Dry System), and

138 subsequently weighed (g dry weight), homogenized with a mortar and pestle, and stored at room

139 temperature in clear borosilicate 40-mL vials (Peterson et al., 2005).

141 2.3. Mercury analysis

Total mercury $(\mathrm{Hg})$ was measured in the muscle biopsies and stomach contents (i.e.,

144 "recovered" prey) of striped bass and tautog, and whole-body samples of "bioavailable" prey

145 using a DMA-80 Direct Mercury Analyzer (Cizdziel et al., 2002). For all target fish and prey, a

146 sub-sample of freeze-dried/homogenized tissue ( $40 \mathrm{mg})$ was added to the mercury analyzer.

147 The instrument has a detection limit of $0.01 \mathrm{ng} \mathrm{Hg}$ (typical working range 0.05-600 ng), and

148 employs thermal decomposition, amalgamation, and atomic absorption spectrophotmetry (EPA

149 Method 7473; U.S. EPA, 1998). The mercury analyzer was calibrated using standard reference

150 materials (SRMs) of known Hg content and prepared by the National Research Council Canada,

151 Institute of Environmental Chemistry (Ottawa, Canada), i.e., TORT-1 (lobster hepatopancreas)

152 and DORM-2 (dogfish muscle). Calibration curves were highly significant (mean $R^{2}=1.00$;

153 range $R^{2}=0.99-1.00 ; p<0.0001$ ), and the recovery of TORT-1, DORM-2, and PACS-2 (marine

154 sediment) SRMs ranged from $91.1 \%$ to $108.3 \%$ (mean $=97.3 \%$ ). For quality control, all

155 samples were analyzed as duplicates (acceptance criteria $=10 \%$ error), and an additional $10 \%$ of 
156 the samples were analyzed as blind replicates (acceptance criteria $=10 \%$ error). For further

157 quality assurance, blanks (i.e., empty quartz boat) were analyzed every 10 samples to assess

158 instrument accuracy and potential drift.

159 Toxic methylmercury ( $\mathrm{MeHg}$ ) typically accounts for the majority of total $\mathrm{Hg}$ in fish

160 tissue (>95\%; Grieb et al., 1990; Bloom, 1992). To ensure the accuracy of this approximation, a

161 sub-sample of striped bass and tautog tissue ( $\mathrm{D}_{0}$ biopsy; $n=11$ for each species) were analyzed

162 for $\mathrm{MeHg}$ (and inorganic $\mathrm{Hg}$ ) concentration by isotope dilution gas chromatography inductively

163 coupled plasma mass spectrometry (GC-ICP-MS) at the Trace Element Analysis Laboratory,

164 Dartmouth College (Hanover, New Hampshire, USA). Fish tissue (30-50 mg dry weight),

165 previously freeze-dried and homogenized, was added to amber glass vials. Approximately 2.65

$166 \mathrm{ng}$ of aqueous $\mathrm{CH}_{3} \mathrm{Hg}^{201}$ was then added as the enriched isotope spike to the sample, followed by

$16710 \mathrm{ml}$ of $4 \mathrm{~mol} \mathrm{l}^{-1} \mathrm{HNO}_{3}$ (Hintelmann and Nguyen, 2005). The entire sample was heated over

168 night at $55^{\circ} \mathrm{C}$, after which a $50-\mu l$ sub-sample of the extract was analyzed by purge and trap,

169 thermal desorption GC-ICP-MS (Rodriguez Martin-Doimeadios et al., 2002). This process

170 includes the ethylation and trapping of volatile $\mathrm{Hg}$ species on Tenax traps (Brooks Rand, Seattle,

171 Washington, USA), followed by thermal desorption onto open column GC and $\mathrm{Hg}$ isotope

172 detection by ICP-MS (Element2, Thermo-Finnegan, Bremen, Germany). The recovery of $\mathrm{MeHg}$

173 in TORT SRM was $94.8 \%$ (range $=91.5-96.2 \%$ ) and sample precision for duplicate runs was

$17499.2 \%($ range $=96.6-102.2 \%)$.

175 Total Hg levels measured by the DMA-80 Direct Mercury Analyzer were in good 176 agreement with the isotope dilution ICP-MS method ( $\mathrm{MeHg}+$ inorganic $\mathrm{Hg}=$ total $\mathrm{Hg})(\mathrm{Linear}$

177 regression: $\left.R^{2}=0.902 ; p<0.0001 ; y=0.7659 x+0.0325\right)$. Total $\mathrm{Hg}$ was higher $(10.7 \%)$ in 178 samples analyzed by the DMA-80 Direct Mercury Analyzer (mean $=0.255 \pm 0.032 \mathrm{mg} \mathrm{Hg} \cdot \mathrm{kg}$ 
179 wet weight $^{-1}$ ) relative to the ICP-MS method (mean $=0.227 \pm 0.026 \mathrm{mg} \mathrm{Hg} \cdot \mathrm{kg}_{\text {wet }}$ weight $^{-1}$ ).

180 This difference was not statistically significant (one-way ANOVA: $F=0.16, d f=1,43, p=$

181 0.693), however, and total $\mathrm{Hg}$ concentrations are hereafter reported for the DMA-80 Analyzer

182 only.

183

184 2.4. Stable isotope analysis

185

Nitrogen and carbon isotope measurements of a sub-sample of freeze-dried target fish $\left(\mathrm{D}_{0}\right.$

187 biopsy; $n=18$-20) and bioavailable prey (whole-body; $n=18-20$ ) were performed by the Boston

188 University Stable Isotope Laboratory (Boston, Massachusetts, USA). Samples of animal ( 1 mg

189 dry weight) were analyzed using automated continuous-flow isotope ratio mass spectrometry

190 (Preston and Owens, 1983). Samples were combusted in a EuroVector Euro EA elemental

191 analyzer (Eurovector, Milan, Italy), after which $\mathrm{N}_{2}$ and $\mathrm{CO}_{2}$ gases were separated on a GC

192 column, passed through a reference gas box, and introduced to an GV Isoprime isotope ratio

193 mass spectrometer (GV Instruments, Manchester, UK). Ratios of ${ }^{13} \mathrm{C} /{ }^{12} \mathrm{C}$ and ${ }^{15} \mathrm{~N} /{ }^{14} \mathrm{~N}$ were

194 expressed as the relative per mil (\%o) difference between the samples and international standards

195 (Vienna Peedee Belemnite carbonate, ${ }^{13} \mathrm{C}_{\mathrm{V}-\mathrm{PDB}}$, and atmospheric nitrogen, ${ }^{15} \mathrm{~N}_{\mathrm{air}}$, respectively):

196

$197 \delta X=\left(R_{\text {sample }} / R_{\text {standard }}-1\right) \times 1000(\% o)$

199 where, $X={ }^{13} \mathrm{C}$ or ${ }^{15} \mathrm{~N}$ and $R={ }^{13} \mathrm{C} /{ }^{12} \mathrm{C}$ or ${ }^{15} \mathrm{~N} /{ }^{14} \mathrm{~N}$. The sample isotope ratio was compared to a

200 secondary gas standard, whose isotope ratio was calibrated to international standards $\left(\mathrm{R}_{\text {standard }}\right)$.

201 For ${ }^{13} \mathrm{C}_{\mathrm{V}-\mathrm{PDB}}$, the gas was calibrated against NBS 20 (Solenhofen limestone). For ${ }^{15} \mathrm{~N}_{\text {air }}$, the gas 
202 was calibrated against atmospheric $\mathrm{N}_{2}$ and ammonium sulfate standards (IAEA standards $\mathrm{N}-1$,

203 N-2, and N-3). All international standards were obtained from the National Bureau of Standards

204 in Gaithersburg, Maryland, USA.

\subsection{Statistical analyses}

Prior to parametric statistical analysis, total $\mathrm{Hg}$ data were converted to wet weight using a

209 wet/dry ratio measured for a sub-sample of striped bass, tautog, and bioavailable prey (Tables 1

210 and 2). Data were then $\log _{10}$-transformed or arc-sin square-root transformed (proportional data)

211 to meet assumptions of normality and homogeneity of variance. Mean $\mathrm{Hg}$ concentrations among

212 muscle biopsies taken from striped bass $(n=18)$ and tautog $(n=14)$ were statistically compared

213 with independent one-way analysis of variance (ANOVA) models using biopsy location ( $\mathrm{D}_{0-3}$

214 and $\mathrm{L}_{1-3}$ biopsies; Fig. 2A) as a fixed factor. Note that the $\mathrm{Hg}$ content of a single muscle biopsy

215 represents the average calculated for the left and right side of the fish. Interspecies differences in

216 muscle mercury levels (total $\mathrm{Hg}$ and \% $\mathrm{MeHg}$ ), stomach content $\mathrm{Hg}$ levels (recovered prey), and

217 isotopic signatures $\left(\delta^{15} \mathrm{~N}\right.$ and $\left.\delta^{13} \mathrm{C}\right)$ were analyzed with one-way ANOVA models using species

218 (striped bass and tautog) as a fixed factor. The effects of target fish TL (cm) and age (yr) on

219 total $\mathrm{Hg}$ concentration were analyzed with least-squares (non-linear) exponential regressions.

220 The ages of individual striped bass and tautog were estimated from species-specific age-size

221 relationships reported in the literature (Hostetter and Munroe, 1993; Nelson et al., 2006). To

222 assess differences in $\mathrm{Hg}$ bioaccumulation rates between striped bass and tautog, two-way

223 ANOVA models were used to test for homogeneity of slopes (i.e., interaction effects between

224 size/age and species) of the linearized exponential regressions (semi-logarithmic transformation). 
The total $\mathrm{Hg}$ concentration and isotopic signature of bioavailable prey were analyzed

226 with a one-way ANOVA models using prey species as a fixed factor. Mean differences in total

$227 \mathrm{Hg}$ levels and isotopic signatures across 8 and 7 levels of prey, respectively, were contrasted

228 with a Ryan-Einot-Gabriel-Welsch (Ryan's Q) multiple comparison test. Note that direct

229 statistical comparisons of the $\mathrm{Hg}$ content and isotope values of target fish and bioavailable prey

230 were not made because of the different tissues analyzed between the groups (i.e., dorsal muscle

231 versus whole-body tissues, respectively) (Gray, 2002). Non-linear exponential regression

232 analysis was used, however, to test for the effect of trophic position $\left(\delta^{15} \mathrm{~N}\right)$ and carbon sources

$233\left(\delta^{13} \mathrm{C}\right)$ on the transfer total $\mathrm{Hg}$ through the estuarine food web.

\section{3. Results}

\subsection{Evaluation of mercury analysis methods}

There was no significant difference in the mean total $\mathrm{Hg}$ concentration among muscle

240 biopsies from an individual striped bass or tautog (one-way ANOVA; bass: $F=0.15, d f=6,125$,

$241 p=0.989$; tautog: $F=0.12, d f=6,97, p=0.994)($ Fig. 2). The Hg concentration of tissue located

242 above the operculum ( $\mathrm{D}_{0}$ biopsy; Fig. $2 \mathrm{~A}$ ) is therefore indicative of the contaminant present in

243 the whole-body white muscle filet, and $\mathrm{Hg}$ levels in target fish are hereafter reported for the $\mathrm{D}_{0}$

244 biopsy only. Mercury speciation analysis also revealed that $\mathrm{MeHg}$ accounts for $>98 \%$ (range $=$

$24596.3-99.6 \%$ ) of the total $\mathrm{Hg}$ present in the muscle tissue of striped bass and tautog (Table 1). To

246 this end, measurements of total $\mathrm{Hg}$ are a suitable approximation of $\mathrm{MeHg}$ in the white muscle

247 tissue of target fish. 
3.2. Mercury analysis of target fish

Total $\mathrm{Hg}$ levels in the dorsal muscle tissue of target fish $(n=119)$ ranged from 0.03 to

$0.58 \mathrm{mg} \mathrm{Hg} \cdot \mathrm{kg}$ wet $\mathrm{wt}^{-1}$ (Table 1). Of these samples, the mean total $\mathrm{Hg}$ concentration of tautog was $33.3 \%$ greater than values measured in striped bass (Table 1). To account for differences in age-at-catch, total $\mathrm{Hg}$ data were standardized by the estimated age of each fish. Accordingly, age-normalized $\mathrm{Hg}$ levels of striped bass were $47.4 \%$ higher than concentrations measured in 256 tautog. both target fish (Exponential regression; bass: $F=50.35, d f=1,65, p<0.0001$; tautog: $F=$

$25986.28, d f=1,52, p<0.0001)($ Fig. 3A). However, the slope of the linearized exponential

260 regression model for tautog $(\beta=0.022)$ was greater than striped bass $(\beta=0.013)$ (two-way

261 ANOVA; species $\times$ length: $F=7.98, d f=3,118, p<0.01)$, indicating that tautog have higher Hg

262 concentrations at a given body length. Total $\mathrm{Hg}$ concentration also increased significantly with

263 fish age, irrespective of species (Exponential regression; bass: $F=56.15, d f=1,65, p<0.0001$;

264 tautog: $F=82.13, d f=1,52, p<0.0001$ ) (Fig. 3B). In contrast to the mercury-length

265 relationship, however, $\mathrm{Hg}$ bioaccumulation rates as a function of age were significantly faster in 266 striped bass than tautog $(\beta=0.133$ and 0.065 , respectively) (two-way ANOVA; species $\times$ age: $F$ $267=13.17, d f=3,118, p<0.0005)$.

268 Of the target fish analyzed in this study, $12.1 \%$ of striped bass and $30.2 \%$ of tautog 269 exceeded the U.S. Environmental Protection Agency advisory level of $0.3 \mathrm{mg} \mathrm{MeHg} \cdot \mathrm{kg}$ wet $270 \mathrm{wt}^{-1}$ (U.S. EPA, 2006). Data were also analyzed with respect to legal-size limits for each 
271 species, i.e., minimum catch size for striped bass and tautog in Rhode Island equal 70.2 and 40.6

$272 \mathrm{~cm}$, respectively (RIDEM, 2008). The mean total Hg concentration of legal-size striped bass

273 was $0.342 \pm 0.040 \mathrm{mg} \mathrm{Hg} \cdot \mathrm{kg}$ wet $\mathrm{wt}^{-1}(n=4)$, of which $75.0 \%$ exceeded the U.S. EPA advisory

274 level. For legal-size tautog, the mean total $\mathrm{Hg}$ concentration was $0.319 \pm 0.027 \mathrm{mg} \mathrm{Hg} \cdot \mathrm{kg}$ wet

$275 \mathrm{wt}^{-1}(n=29)$, and $44.8 \%$ of these fish had $\mathrm{Hg}$ levels above $0.3 \mathrm{mg} \mathrm{MeHg} \cdot \mathrm{kg} \mathrm{wet} \mathrm{wt} \mathrm{H}^{-1}$. The

276 mercury-length exponential regression model also predicted that striped bass and tautog attain

$277 \mathrm{Hg}$ concentrations equal to the U.S. EPA advisory level near their minimum legal catch size

278 (75.7 and $48.6 \mathrm{~cm}$ TL, respectively; Fig. 3A).

279

280 3.3. Stomach content analysis

The stomach contents of striped bass and tautog revealed interspecies differences in diet

283 (Table 3). The results suggest that striped bass are opportunistic foragers, as bass consumed 10

284 different recovered prey species. Teleost fish and decapod crustaceans (sand shrimp and green

$285 \mathrm{crab}$ ) comprised the largest fraction of the striped bass diet. Collectively, these prey items were

286 identified in $29.4 \%$ of the stomachs analyzed. Only 5 novel prey taxa were positively identified

287 in tautog stomachs (Table 3); hence, relative to bass, tautog demonstrate a selective foraging

288 strategy. The blue mussel and decapod crabs (green, mud, and unidentified crabs) were the

289 preferred prey of tautog, occurring in $43.0 \%$ of the stomachs.

290

291 3.4. Mercury analysis of prey

292 
The principal prey of striped bass and tautog, as determined by dietary analysis, were

294 collected from the Narragansett Bay and subsequently analyzed for whole-body total Hg. Mean total $\mathrm{Hg}$ levels of these bioavailable prey varied significantly as a function of prey-type (one-way ANOVA; $F=29.70, d f=7,835, p<0.0001)$ (Table 2). With the exception of the Atlantic menhaden, prey that were exclusive to striped bass (anchovy, herring, scup, and sand shrimp)

298 had significantly higher $\mathrm{Hg}$ concentrations than the prey of tautog (blue mussel and mud crab) 299 (Ryan's Q multiple comparison test) (Fig. 4). On average, the total Hg concentration of tautog 300 prey was $32.0 \%$ lower than the diet items of striped bass. The mean total $\mathrm{Hg}$ concentration of 301 prey removed from tautog stomachs was also $13.2 \%$ lower than the recovered prey of striped 302 bass, but this difference was not significant at $p<0.05$ (Table 1 ).

310 values varied significantly across species (one-way ANOVA; $F=57.99, d f=6,136, p<0.0001$ ).

311 Specifically, significant ${ }^{15} \mathrm{~N}$ enrichment was observed in scup and bay anchovy, whereas the

312 most depleted $\delta^{15} \mathrm{~N}$ values were calculated for Atlantic menhaden and blue mussel (Table 2; Fig.

313 5) (Ryan's Q multiple comparison test).

314 The $\delta^{15} \mathrm{~N}$ value of the blue mussel was used to assign distinct trophic levels for each 315 consumer species analyzed in this study (modified from Hobson et al., 2002). 
317 Trophic level $=2+\frac{\left(\delta^{15} N_{\text {consumer }}-\delta^{15} N_{\text {mussel }}\right)}{3.4}$

319 where, "2" is the assumed trophic level of the blue mussel, a phytoplanktivore (Newell, 1989),

$320 \quad \delta^{15} \mathrm{~N}_{\text {mussel }}$ and $\delta^{15} \mathrm{~N}_{\text {consumer }}$ are the respective nitrogen isotope signatures of blue mussel (10.62\% ;

321 this study) and the consumer species of interest, and "3.4" is the constant nitrogen isotope

322 enrichment (\%o) per trophic level (Post, 2002). Accordingly, striped bass and tautog were

323 designated a trophic level of $4.07 \pm 0.08$ and $3.51 \pm 0.03$, respectively, whereas prey species

324 (excluding mussels) occupied trophic levels between 2.43 and 3.26 (Tables 1 and 2).

325 Stable carbon $\left(\delta^{13} \mathrm{C}\right)$ isotope signatures were used to determine the varying sources of

326 primary production to the estuarine food web (e.g., benthic algae versus phytoplankton), and

327 thus, distinguish between benthic and pelagic trophic linkages (Peterson and Howarth, 1987;

328 France, 1995). Measured $\delta^{13} \mathrm{C}$ values ranged from $-20.16 \pm 0.17 \%$ o to $-15.13 \pm 0.25 \%$ and

329 varied significantly between target fish (Table 1 ) and among prey (one-way ANOVA; $F=40.66$,

$330 d f=6,136, p<0.0001$ ) (Table 2). Moreover, two distinct isotopic groups were demarcated by a

$331 \delta^{13} \mathrm{C}$ value of approximately $-18 \%$ (Fig. 5). Relative to this demarcation point, more depleted

$332 \quad \delta^{13} \mathrm{C}$ values indicate a phytoplankton-based (pelagic) food web, and in this study were

333 represented by the striped bass, planktivorous forage fish, and blue mussels. Conversely, $\delta^{13} \mathrm{C}$

334 signatures greater than -18\%o (i.e., more enriched) suggest benthic sources of primary production

335 and were characteristic of tautog, scup, and decapod crustaceans.

336 Stable isotope analysis was coupled with total $\mathrm{Hg}$ data to provide insight into the effects

337 of trophic structure on species contamination. There was a significant positive correlation

338 between mean total $\mathrm{Hg}$ concentration and $\delta^{15} \mathrm{~N}$ values measured for target fish and bioavailable 
prey (Exponential regression; $F=38.79, d f=1,8, p<0.0005$ ) (Fig. 6); hence verifying an

340 increase in $\mathrm{Hg}$ contamination at higher trophic levels in the estuarine food web. Conversely, no

341 significant relationship was observed between mean total $\mathrm{Hg}$ concentration and $\delta^{13} \mathrm{C}$ values

342 measured across all species (Exponential regression; $F=0.20, d f=1,7, p=0.670$ ).

\section{4. Discussion}

\subsection{Mercury analysis of target fish}

This study provides information on $\mathrm{Hg}$ levels in the muscle tissue of striped bass and

349 tautog collected from the Narragansett Bay, and also examines the effect of several biotic factors

350 on interspecies $\mathrm{Hg}$ bioaccumulation patterns. A significant positive correlation between $\mathrm{Hg}$

351 concentration and target fish age (and size) was observed for striped bass and tautog, and similar

352 patterns have been previously documented for each species (Hammerschmidt and Fitzgerald,

353 2006a; Mason et al., 2006). The Hg-age relationship confirms that striped bass and tautog

354 effectively bioaccumulate $\mathrm{Hg}$, which is further explained by a low rate of $\mathrm{Hg}$ depuration relative

355 to the rapid accumulation of $\mathrm{Hg}$ in fish muscle tissue (Clarkson, 1992; Trudel and Rasmussen,

356 1997). It is well established that dietary uptake is the dominant source of $\mathrm{Hg}$ in fish (Hall et al.,

357 1997); however, striped bass bioaccumulate $\mathrm{Hg}$ at an accelerated rate relative to tautog. For

358 example, the slope of the linearized exponential (Hg-age) regression provides an estimate of the

$359 \mathrm{Hg}$ bioaccumulation rate for a given species. The comparison of these slope values between the

360 target fish predicts that striped bass $(\beta=0.133)$ accumulate $\mathrm{Hg}$ in muscle tissue twice as fast as

361 tautog $(\beta=0.065)$. As discussed in the subsequent section, differences in diet and trophic 
362 positioning in the estuarine food web likely account for the observed patterns of $\mathrm{Hg}$

363 bioaccumulation in the target fish (Weiner et al., 2003; Bank et al., 2007).

Although striped bass accumulate $\mathrm{Hg}$ more rapidly than tautog, results from this study

365 indicate that the mean $\mathrm{Hg}$ concentration of tautog exceeded levels in bass. This apparent

366 discrepancy is attributed to the greater age-at-catch of tautog (Cooper, 1967), and thus,

367 protracted period in which this species is exposed to $\mathrm{Hg}$. Specifically, the average age of tautog

368 in this study was 2.6 times greater than striped bass; hence, at a given body length, tautog had a

369 higher $\mathrm{Hg}$ tissue concentration than bass. A similar explanation was provided by

370 Hammerschmidt and Fitzgerald (2006a) to reconcile the difference in $\mathrm{Hg}$ concentrations

371 observed in tautog and bluefish (Pomatomus saltatrix), an apex piscivore, from the Long Island

372 Sound. To this end, the authors recommended that fish longevity be considered when assessing

373 their potential risk to human consumers (Hammerschmidt and Fitzgerald, 2006a).

374 In this investigation, $\mathrm{Hg}$ concentrations of tautog were comparable to values observed in

375 conspecifics from other coastal ecosystems. Hammerschmidt and Fitzgerald (2006a), using

376 cold-vapor atomic fluorescence spectrometry (CVAFS), analyzed the mercury content of tautog

377 collected from the Long Island Sound (mean TL $=41.4 \mathrm{~cm} ; n=32$ ), and reported an average

$378 \mathrm{MeHg}$ concentration of $0.19 \mathrm{mg} \mathrm{MeHg} \cdot \mathrm{kg}$ wet $\mathrm{wt}^{-1}$ for axial muscle tissue. Moreover, for

379 tautog collected from the New York Bight Apex (mean TL = $31.0 \mathrm{~cm} ; n=14$ ), Deshpande et al.

380 (2000) estimated a mean total $\mathrm{Hg}$ concentration of $0.08 \mathrm{mg} \mathrm{Hg} \cdot \mathrm{kg}_{\text {wet }} \mathrm{wt}^{-1}$ for white muscle

381 tissue. Using the exponential regression presented in this study, tautog of comparable sizes (41.4

382 and $31.0 \mathrm{~cm}$ ) from the Narragansett Bay had projected $\mathrm{Hg}$ values of 0.21 and $0.12 \mathrm{mg} \mathrm{Hg} \cdot \mathrm{kg}$

383 wet $\mathrm{wt}^{-1}$, respectively. 
In contrast to tautog, geographic variability in $\mathrm{Hg}$ contamination was apparent in striped bass. In the Chesapeake Bay, for example, the dorsal muscle tissue of striped bass (mean TL $66 \mathrm{~cm} ; n=70$ ) had a mean MeHg concentration of $0.12 \mathrm{mg} \mathrm{MeHg} \cdot \mathrm{kg}$ wet $\mathrm{wt}^{-1}$ (analyzed using

387 CVAFS; Mason et al., 2006). This level of contamination is considerably lower then the estimated $\mathrm{MeHg}$ content of striped bass from the Narragansett Bay that are of the same TL (0.22 $\mathrm{mg} \mathrm{MeHg} \cdot \mathrm{kg}$ wet $\mathrm{wt}^{-1}$; using $\mathrm{Hg}$-size relationship and \% $\mathrm{MeHg}$ data). It is also noteworthy that

390 the mean proportional contribution of $\mathrm{MeHg}$ to total $\mathrm{Hg}$ in striped bass from the Chesapeake Bay

391 (65\%; Mason et al., 2006) was lower than the value reported in this study $(98.7 \%)$. Spatial variations in the $\mathrm{Hg}$ burden of marine and estuarine fish are poorly understood,

393 but are presumably a function of geographic differences in the level of $\mathrm{Hg}$ input to the ecosystem 394 and biogeochemical conditions that affect MeHg production and mobilization (Rolfhus and 395 Fitzgerald, 1995; Benoit et al., 2003; Kraepiel et al., 2003; Hammerschmidt and Fitzgerald, 396 2006b). Moreover, spatially-explicit physicochemical variables and predator-prey interactions 397 influence the initial incorporation of $\mathrm{Hg}$ into the food web and its subsequent transfer through 398 trophic assemblages (Lindqvist et al., 1991; Watras and Bloom, 1992; Mason et al., 1996; Bloom 399 et al., 1999; Sveinsdottir and Mason, 2005). The assessment of spatial differences in fish $\mathrm{Hg}$ 400 levels, however, are complicated for those species that exhibit large-scale seasonal migrations 401 and ontogenetic shifts in habitat use and diet, as reported for striped bass (Harding and Mann, 402 2003; Nelson et al., 2003, 2006; Secor and Piccoli, 2007). 
Visual analysis of the stomach contents of tautog and striped bass revealed differences in

407 their feeding strategy and diet composition. Tautog exhibited a strict durophagous foraging

408 strategy, and therefore fed exclusively on hard-bodied epibenthic and encrusting invertebrates.

409 Macrocrustaceans were also numerically dominant prey for striped bass, although dietary overlap

410 with tautog was minimal. Further, striped bass were piscivorous, with teleosts accounting for a

411 large proportion of the identified diet. These results are consistent with previous analyses of the

412 food habits of tautog and striped bass collected from other coastal Atlantic regions, including the

413 Chesapeake Bay (Hildebrand and Schroeder, 1928; Hartman and Brandt, 1995; Harding and

414 Mann, 2003; Walter and Austin, 2003), Delaware Bay (Steimle and Shaheen, 1999), New York-

415 New Jersey estuarine waters (Olla et al., 1974; Festa, 1979; Steimle and Ogren, 1982), and

416 Massachusetts coastal waters (Nelson et al., 2003, 2006).

417 Measurements of interspecies $\delta^{13} \mathrm{C}$ signatures corroborated the findings of the

418 conventional dietary analysis of target fish. Specifically, tautog had a $\delta^{13} \mathrm{C}$ signature consistent

419 with a benthic carbon source and presumably derived from the consumption of epibenthic

420 crustaceans. It was evident, however, that tautog maintained a lower $\delta^{13} \mathrm{C}$ value than its

421 principal crustacean prey, the green crab. This discrepancy is attributed to the substantial

422 contribution of the blue mussel, a phytoplanktivore (Newell, 1989), to the diet of tautog. In

423 contrast to tautog, striped bass had a $\delta^{13} \mathrm{C}$ signature characteristic of a pelagic carbon source,

424 which in turn resulted from bass feeding on forage fish. The slightly more enriched $\delta^{13} \mathrm{C}$

425 signature of striped bass relative to planktivorous forage fish, however, may reflect the additional

426 contribution of decapod crustaceans to the diet of bass.

427 The diet and trophic ecology of striped bass and tautog are the main factors impacting

428 their respective $\mathrm{Hg}$ bioaccumulation rates. In this study, species-specific $\delta^{15} \mathrm{~N}$ signatures 
429 indicate that striped bass occupy a higher trophic position than tautog (trophic level $\sim 4.1$ and

4303.5 , respectively). The variation in trophic status between target fish is adequately explained by

431 the trophic positioning of their prey. Striped bass, for example, feed on relatively high trophic

432 level prey (forage fish and decapod crustaceans; mean trophic level $=2.86$ ), whereas tautog

433 consume prey that occupy lower trophic levels (mussel and green crab; mean trophic level=

434 2.33). The analysis of $\mathrm{Hg}$ levels in bioavailable prey further revealed that striped bass feed on

$435 \mathrm{Hg}$-enriched prey relative to the dietary items of tautog (mean $\mathrm{Hg}$ content of prey $=0.03$ and

$4360.02 \mathrm{mg} \mathrm{Hg} \cdot \mathrm{kg}$ wet $\mathrm{wt}^{-1}$, respectively). The Atlantic menhaden, an important food resource of

437 striped bass (Walter and Austin, 2003; Nelson et al., 2006; this study), was an exception to this

438 observed pattern. The low $\mathrm{Hg}$ content of menhaden was attributed to this species occupying a

439 low trophic position in the estuary $(\sim 2.4)$. This is further supported by a depleted $\delta^{13} \mathrm{C}$ signature

440 in menhaden, which implies that this species consumes phytoplankton (e.g., pelagic diatoms;

441 Collette and Klein-MacPhee, 2002).

442 The positive correlation between $\mathrm{Hg}$ levels and $\delta^{15} \mathrm{~N}$ signatures of sampled biota

443 indicates that $\mathrm{Hg}$ is trophically transferred through the estuarine food web, as reported in other

444 aquatic systems (Jarman et al., 1996; Bowles et al., 2001; Power et al., 2002; Bank et al., 2007;

445 Cai et al., 2007). Precaution must be exercised in this study, however, when evaluating the rate

446 of $\mathrm{Hg}$ increase across trophic levels. This is particularly warranted for direct comparisons

447 between target fish and bioavailable prey because different tissues were analyzed (dorsal muscle

448 and whole-body tissues, respectively). Previous studies have demonstrated that certain body

449 tissues (e.g., muscle, liver) disproportionately concentrate $\mathrm{Hg}$, and thus, have higher $\mathrm{Hg}$ levels

450 than whole-body samples (Gray, 2002; Peterson et al., 2005). If applicable to this investigation,

451 then the muscle tissue of target fish is expected to have modestly inflated $\mathrm{Hg}$ levels relative to 
452 the entire body. Notwithstanding this limitation, the cumulative data presented herein offers

453 compelling evidence that time-integrated diet history and trophic relationships are the dominant

454 factors impacting $\mathrm{Hg}$ bioaccumulation in the Narragansett Bay estuary.

459 fish are relatively low, i.e., only $12.1 \%$ of striped bass and $30.2 \%$ of tautog exceeded the U.S.

460 EPA criterion of $0.3 \mathrm{mg} \mathrm{MeHg} \cdot \mathrm{kg}_{\text {wet }} \mathrm{wt}^{-1}$ (U.S. EPA, 2006). To accurately assess the possible

461 human health risks associated with eating fish, however, contaminant data must be analyzed

462 relative to state-imposed legal-size limits for target species. In this study, reevaluating the $\mathrm{Hg}$

463 data for only legal-size fish revealed that $75.0 \%$ of striped bass and $44.8 \%$ of tautog accumulated

$464 \mathrm{Hg}$ levels beyond the U.S. EPA regulatory threshold. Moreover, the mercury-length exponential

465 model presented in this study suggests that striped bass and tautog obtain $\mathrm{Hg}$ levels of $0.3 \mathrm{mg} \mathrm{Hg}$

$466 \cdot \mathrm{kg}$ wet $\mathrm{wt}^{-1}$ near their minimum legal catch size (75.7 and $48.6 \mathrm{~cm} \mathrm{TL}$, respectively). It is

467 important to note, however, that the low sample size of legal-size target fish, particularly for

468 striped bass $(n=4)$, requires that additional studies be conducted on the $\mathrm{Hg}$ contamination of

469 these edible species. Nevertheless, the results presented in this study indicate that frequent

470 consumption of striped bass and tautog could pose a human health risk, and thus, justify their

471 inclusion in state-specific consumption advisories. Moreover, this exercise underscores the

472 importance of coupling species-specific $\mathrm{Hg}$ data with state-imposed minimum catch

473 requirements; hence, focusing on fishery resources that represent $\mathrm{Hg}$ exposure pathways to

474 human consumers. 
Acknowledgements

We are grateful to J. C. Powell and S. Olszewski (Rhode Island Division of Fish and

479 Wildlife, Jamestown, RI), K. Henry (University of Rhode Island/Graduate School of

480 Oceanography, Narragansett, RI), and J. Szczebak, E. Payne, J. Linehan, S. Helming, L.F. Ho,

481 M. Gardner, and B. Bourque (Roger Williams University, Bristol, RI) for assistance in sample

482 collection and preparation. We thank R. Michener (Boston University Stable Isotope Laboratory,

483 Boston, MA) and B. Jackson (Dartmouth College, Trace Metals Laboratory, Hanover, NH) for

484 stable isotope and methylmercury analyses, respectively. We also thank D. Nacci and J. Lake

485 (U.S. Environmental Protection Agency, Atlantic Ecology Division, Narragansett, RI) and M.

486 Bank (Harvard School of Public Health, Department of Environmental Health, Boston, MA) for

487 suggestions on experimental design and for scientific/editorial reviews that greatly improved this

488 manuscript. The project described was supported by Award Number P20RR016457 from the

489 National Center for Research Resources. The content is solely the responsibility of the authors

490 and does not necessarily represent the official views of the National Center for Research

491 Resources or the National Institutes of Health. 


\section{References}

Able, K.W., 2005. A reexamination of fish estuarine dependence: evidence for connectivity between estuarine and ocean habitats. Estuaries, Coastal and Shelf Science 64, 5-17.

Able, K.W., Fahay, M.P., 1998. The first year in the life of estuarine fishes in the Middle Atlantic Bight, Rutgers University Press, New Brunswick, NJ, 342 p.

Bank, M.S., Chesney, E., Shine, J.P., Maage, A., Seen, D.B., 2007. Mercury bioaccumulation and trophic transfer in sympatric snapper species from the Gulf of Mexico. Ecological Applications 17, 2100-2110.

Benoit, J.M., Gilmour, C.C., Heyes, A., Mason, R.P., Miller, C.L., 2003. Geochemical and biological controls over methylmercury production and degradation in aquatic ecosystems. In: Biogeochemistry of environmentally important trace elements. American Chemical Society Publ, ACS symposium series 835, 262-297 pp.

Bloom, N.S., 1992. On the chemical form of mercury in edible fish and marine invertebrate tissue. Canadian Journal of Fisheries and Aquatic Sciences 49, 1010-1017.

Bloom, N.S., Gill, G.A., Cappellino, S., Dobbs, D., McShea, L., Driscoll, C., Mason, R.P., Rudd, J., 1999. An investigation regarding speciation and cycling of mercury in Lavaca Bay sediments. Environmental Science and Technology 33, 7-13.

Bowles, K.C., Apte, S.C., Maher, W.A., Kawei, M., Smith, R., 2001. Bioaccumulation and biomagnification of mercury in Lake Murray, Papua New Guinea. Canadian Journal of Fisheries and Aquatic Sciences 58, 888-897.

Briggs, P.T., 1977. Status of tautog populations at artificial reefs in New York waters and effects of fishing. New York Fish and Game Journal 24, 154-167. 
515 Cai, Y., Rooker, J.R., Gill, G.A., Turner, J.P., 2007. Bioaccumulation of mercury in pelagic

516 fishes from northern Gulf of Mexico. Canadian Journal of Fisheries and Aquatic Sciences

$517 \quad 64,458-469$.

518 Cizdziel, J.V., Hinners, T.A., Pollard, J.E., Heithmar, E.M., Cross, C.L., 2002. Mercury

519 concentrations in fish from Lake Mead, USA, related to fish size, condition, trophic level,

520 location, and consumption risk. Archives of Environmental Contamination and

$521 \quad$ Toxicology 43, 309-317.

522 Clarkson, T.W., 1992. Mercury: major issues in environmental health. Environmental Health

$523 \quad$ Perspectives 100, 31-38.

524 Collette, B.B., Klein-MacPhee, G. (eds.)., 2002. Bigelow and Schroeder's Fishes of the Gulf of

525 Maine ( $3^{\text {rd }}$ edition). Smithsonian Inst. Press. Washington, D.C., 748 p.

526 Collie, J.S., Wood, A.D., Jeffries, H.P., 2008. Long-term shifts in the species composition of a

527 coastal fish community. Canadian Journal of Fisheries and Aquatic Sciences 65, 1352-

$528 \quad 1365$.

529 Cooper, R.A., 1967. Age and growth of the tautog, Tautoga onitis (Linnaeus) from Rhode Island.

$530 \quad$ Transactions of the American Fisheries Society 96, 134-142.

531 Deshpande, A.D., Draxler, A.F.J., Zdanowicz, V.S., Schrock, M.E., Paulson, A.J., Finneran,

532 T.W., Scharack, B.L., Corbo, K., Arlen, L., Leimburg, E.A., Dockum, B.W., Pikanowski,

533 R.A., May, B., Rosman, L., 2000. Contaminant levels in muscle of four species of

534 recreation fish from the New York Bight Apex. NOAA Tech Mem NMFS-NE-157

535 National Marine Fisheries Service, Woods Hole, Massachusetts.

536 Festa, P.J., 1979. The fish forage base of the Little Egg Harbor Estuary. New Jersey Bureau of

537 Fishery Technical Report. 24M, 271 pp. 
538

539

540

541

542

543

544

545

546

547

548

549

550

551

552

553

554

555

556

557

558

559

Fitzgerald, W.F., Clarkson, T.W., 1991. Mercury and monomethylmercury: Present and future concerns. Environmental Health Perspectives 96, 159-166.

France, R.L., 1995. Carbon-13 enrichment in benthic compared to planktonic algae: food web implications. Marine Ecology Progress Series 124, 307-312.

Fry, B., Sherr, E.B., 1984. $\delta^{13}$ C measurements as indicators of carbon flow in marine and freshwater ecosystems. Contributions in Marine Science 27, 13-47.

Grandjean, P., Weihe, P., White, R., Debes, F., Arak, S., Yokoyama, K., Murata, K., Sorensen, N., Dahl, R., Jorgensen, P., 1997. Cognitive deficit in 7-year-old children with prenatal exposure to methylmercury. Neurotoxicology and Teratology 20, 1-12.

Gray, J.S., 2002. Biomagnification in marine systems: the perspective of an ecologist. Marine Pollution Bulletin 45, 46-52.

Grieb, T.M., Driscoll, C., Gloss, S., Schofield, C., Bowie, G., Porcella, D., 1990. Factors affecting mercury accumulation in fish in the Upper Michigan Peninsula. Environmental Toxicology and Chemistry 9, 919-930.

Hall, B.D., Bodaly, R.A., Fudge, R.J., Rudd, J.W., Rosenberg, D.M., 1997. Food as the dominant pathway of methylmercury uptake by fish. Water, Air, and Soil Pollution 100, 13-24.

Hammerschmidt, C.R., Fitzgerald, W.F., 2006a. Bioaccumulation and trophic transfer of methylmercury in Long Island Sound. Archives of Environmental Contamination and Toxicology 51, 416-424.

Hammerschmidt, C.R., Fitzgerald, W.F., 2006b. Methylmercury cycling in sediments on the continental shelf of southern New England. Geochimica et Cosmochimica Acta 70, 918930. 
Harding, J.M., Mann, R., 2003. Influence of habitat on diet and distribution of striped bass (Morone saxatilis) in a temperate estuary. Bulletin of Marine Science 72, 841-851.

Hartman, K.L., Brandt, S.B., 1995. Trophic resource partitioning, diets, and growth of sympatric estuarine predators. Transactions of the American Fisheries Society 124, 520-537.

Hightower, J.M., Moore, D., 2003. Mercury levels in high-end consumers of fish. Environmental Health Perspectives 111, 1-6.

Hintelmann, H., Nguyen, H.T., 2005. Extraction of methylmercury from tissue and plant samples by acid leaching. Analytical and Bioanalytical Chemistry 381, 360-365.

Hildebrand, S.F., Schroeder, W.C., 1928. Fishes of Chesapeake Bay. Fishery Bulletin 43, 388 pp.

Hobson, K.A., Fish, A., Karnovsky, N., Holst, M., Gagnon, J.-M., Fortier, M., 2002. A stable isotope $\left(\delta^{13} \mathrm{C}, \delta^{15} \mathrm{~N}\right)$ model for the North Water food web: implications for evaluating trophodynamics and the flow of energy and contaminants. Deep-Sea Research II 49, 5131-5150.

Hostetter, E.B., Munroe, T.A., 1993. Age, growth, and reproduction of tautog Tautoga onitis (Labridae: Perciformes) from coastal waters of Virginia. Fishery Bulletin 91, 45-64.

Jarman, W.M., Hobon, K.A., Sydeman, W.J., Bacon, C.E., McLaren, E.B., 1996. Influence of trophic position and feeding location on contaminant levels in the Gulf of the Farallones food web revealed by stable isotope analysis. Environmental Science and Technology 30, 654-660.

Kraepiel, A.M.L., Keller, K., Chin, H.B., Malcolm, E.G., Morel, F.M.M., 2003. Sources and variations of mercury in tuna. Environmental Science and Technology 37, 5551-5558.

Lindqvist, O., Johansson, K., Astrup, M., Andersson, A., Bringmark, L., Hovsenius, G., 
Hakanson, L., Iverfeldt, A., Meili, M., Timm, B., 1991. Mercury in the Swedish environment: Recent research on causes, consequences and corrective methods. Water, Air, and Soil Pollution 55, 1-252.

Lynch, T., 2000. Assessment of recreationally important finfish stocks in Rhode Island waters. Coastal Fishery Resource Assessment Trawl Survey. Rhode Island Department of Management, Division of fish and Wildlife. Government Center, Wakefield, Rhode Island.

Mason, R.P., Reinfelder, J.R., Morel, F.M.M., 1996. Uptake, toxicity, and trophic transfer of mercury in a coastal diatom. Environmental Science and Technology 30, 1835-1845.

Mason, R.P., Heyes, D., Sveinsdottir, A., 2006. Methylmercury concentrations in fish from tidal waters of the Chesapeake Bay. Archives of Environmental Contamination and Toxicology 51, 425-437.

Michener, R.H., Schell, D.M., 1994. Stable isotope ratios as tracers in marine and aquatic food webs. In: Lajtha, K., Michener, R.H. (eds.), Stable isotopes in ecology and environmental science. Blackwell Scientific Publications, Oxford, pp. 138-157.

Moszczynski, P., Lisiewicz, J., Bartus, R., Bem, S., 1990. The serum immunoglobulins in workers after prolonged occupational exposure to the mercury vapors. Med Intern 28, 2530.

National Marine Fisheries Service, Fisheries Statistics Division, 2007. http://www.st.nmfs.noaa.gov/st1/. Accessed 5 September 2008.

Nelson, G. A., Chase, B.C., Stockwell, J.D., 2003. Food habits of striped bass (Morone saxatilis) in coastal waters of Massachusetts. Journal of Northwest Atlantic Fishery Science 32, 125. 
606

607

608

609

610

611

612

613

614

615

616

617

618

619

620

621

622

623

624

625

626

627

628

Nelson, G. A., Chase, B.C., Stockwell, J.D., 2006. Population consumption of fish and invertebrate prey by striped bass (Morone saxatilis) from coastal waters of northern Massachusetts , USA. Journal of Northwest Atlantic Fishery Science 36, 111-126.

Newell, R.I.E., 1989. Species profiles: life histories and environmental requirements of coastal fishes and invertebrates (North and Mid-Atlantic). Blue mussel. U.S. Fish. Wildl. Serv. Biol. Rep. 82(11. 102). U.S. Army Corps of Engineers, TR El-82-4. 25 pp.

Olla, B.L., Bejda, A.J., Martin, A.D., 1974. Daily activity, movements, feeding, and seasonal occurrence in the tautog, Tautoga onitis. Fishery Bulletin 72, 27-35.

Olla, B.L., Bejda, A.J., Martin, A.D., 1979. Seasonal dispersal and habitat selection of cunner, Tautogolabrus adspersus, and young tautog, Tautoga onitis, in Fire Island Inlet, Long Island, New York. Fishery Bulletin 77, 255-261.

Oviatt, C.A., Nixon, S.W., 1973. The demersal fish of Narragansett Bay: an analysis of community structure, distribution and abundance. Estuarine, Coastal and Shelf Science 1, 361-378.

Perna, L., LaCroix-Fralish, A., Stürup, S., 2005. Determination of inorganic mercury and methylmercury in zooplankton and fish samples by speciated isotopic dilution GC-ICPMS after alkaline Digestion. Journal of Analytical Atomic Spectrometry 20, 236-238.

Peterson, B.J., Howarth, R.W., 1987. Sulfur, carbon, and nitrogen isotopes used to trace organicmatter flow in the salt-marsh estuaries of Sapelo Island, Georgia. Limnology and Oceanography 32, 1195-1213.

Peterson, S.A., Van Sickle, J., Hughes, R.M., Schacher, J.A., Echols, S.F., 2005. A biopsy procedure for determining filet and predicting whole-fish mercury concentration. Archives of Environmental Contamination and Toxicology 48, 99-107. 
629 Post, D.M., 2002. Using stable isotopes to estimate trophic positions: Models, methods, and assumptions. Ecology 83, 703-718.

631 Power, M., Klein, G.M., Guiguer, K.R.R.A., Kwan, M.K.H., 2002. Mercury accumulation in the fish community of a sub-Arctic lake in relation to trophic position and carbon sources.

634 Preston, T., Owens, N.J.P., 1983. Interfacing an automatic elemental analyzer with an isotope ratio mass spectrometer: the potential for fully automated total nitrogen and nitrogen-15 analysis. The Analyst 108, 971-977.

Pruell, R.J., Taplin, B.K., Lake, J.L., Jayaraman, S., 2006. Nitrogen isotope ratios in estuarine biota collected along a nutrient gradient in Narragansett Bay, Rhode Island, USA. Marine Pollution Bulletin 52, 612-620.

Rhode Island Department of Environmental Management (RIDEM), 2008. Rhode Island Marine Fisheries Statutes and Regulations, Part VII - Minimum Sizes of Fish/Shellfish. Rhode Island Department of Environmental Management, Bureau of Natural Resources, Fish

644 Rodriguez Martin-Doimeadios, R.C., Krupp, E., Amouroux, D., Donard, O.F.X., 2002. Application of isotopically labeled methylmercury for isotope dilution analysis of

648 Rolfhus, K.R., Fitzgerald, W.F., 1995. Linkages between atmospheric mercury deposition and biological samples using gas chromatography/ICPMS. Analytical Chemistry 74, 2505the methylmercury content of marine fish. Water, Air, and Soil Pollution 80, 291-297. J., Esterbauer, H., Tatzber, F., Salonen, R., 1995. Intake of mercury from fish, lipid 
peroxidation, and the risk of myocardial infarction and coronary, cardiovascular, and any death in eastern Finnish men. Circulation 91, 645-655.

654 Secor, D.H. 2000. Longevity and resilience of Chesapeake Bay striped bass. ICES Journal of $655 \quad$ Marine Science 57, 808-818.

656 Secor, D.H., Piccoli, P.M., 2007. Oceanic migration rates of Upper Chesapeake Bay striped bass (Morone saxatilis), determined by otolith microchemical analysis. Fishery Bulletin 105, 62-73.

Secor, D.H., Trice, T.M., Hornick, H.T., 1995. Validation of otolith-based ageing and a comparison of otolith scale-based ageing in mark-recaptured Chesapeake Bay striped

Sorensen, N., Murata, K., Budtz-Jorgensen, E., Weihe, P., Grandjean, P., 1999. Prenatal methylmercury exposure as a cardiovascular risk factor at seven years of age. Epidemiology 10, 370-375.

Steimle, F.W., Ogren, L., 1982. Food of fish collected on artificial reefs in the New York Bight and off Charleston, South Carolina. Marine Fishery Review 44, 49-52.

Steimle, F.W., Pikanowski, R.A., McMillan, D.G., Zetlin, C.A., Wilk, S.J., 2000. Demersal fish and American lobster diets in the Lower Hudson-Raritan estuary. NOAA Tech Mem NMFS-NE-161 National Marine Fisheries Service, Woods Hole Massachusetts. onitis) life history and habitat requirement. NOAA Technical Memorandum NMFS-NE118, U.S. Department of Commerce, 23 p.

Sveinsdottir, A.Y., Mason, R.P. 2005. Factors controlling mercury and methylmercury 
concentrations in largemouth bass (Micropterus salmoides) and other fish from Maryland reservoirs. Archives of Environmental Contamination and Toxicology. 49, 528-545.

Thompson, M.R. 2005. Final report of the Rhode Island Commission on mercury reduction and education. Pursuant to RIGL §23-24.9. Submitted to Governor Donald L. Carcieri and the Rhode Island General Assembly, April 2005.

Trudel, M., Rasmussen, J.B., 1997. Modeling the elimination of mercury by fish. Environmental Toxicology and Chemistry 31, 1716-1722.

U.S. Environmental Protection Agency (U.S. EPA), 1997. Mercury Study Report to Congress. Volumes I-VII: Fate and Transport of Mercury in the Environment, EPA-452/R-97-005. U.S. Environmental Protection Agency, Washington, D.C., USA.

U.S. Environmental Protection Agency (U.S. EPA), 1998. Mercury in solids and solutions by thermal decomposition, amalgamation, and atomic absorption spectrophotometry. EPA Method 7473 Report. U.S. Environmental Protection Agency, Washington, D.C., USA.

U.S. Environmental Protection Agency (U.S. EPA), 2006. Draft Guidance for Implementing the January 2001 Methylmercury Water Quality Criterion. EPA 823-B-04-001. U.S. Environmental Protection Agency, Office of Water, Washington, D.C., USA.

Walter, J.F. III, Austin, H.M., 2003. Diet composition of large striped bass (Morone saxatilis) in Chesapeake Bay. Fishery Bulletin 101, 414-423.

Watras, C.J., Bloom, N.S., 1992. Mercury and methylmercury in individual zooplankton: implications for bioaccumulation. Limnology and Oceanography 37, 1313-1318.

Weiner, J.G., Krabbenhoft, D.P., Heinz, G.H., Scheuhammer, A.M. 2003. Ecotoxicology of mercury. Hoffman, D.J. Rattner, B.A., Burton, G.A.J., Cairns, J.J. (eds.) Lewis Publishers, New York. pp. 409-443. 
697 Welsh, S.A., Kahnle, A.W., Versak, B.A., Latour, R.J., 2003. Use of tag data to compare growth rates of Atlantic striped bass stocks. Fisheries Management and Ecology 10, 289-294. 


\section{Figure captions}

700

701 Fig. 1. Map of the Narragansett Bay (Rhode Island, USA) with points denoting collection sites

702 of striped bass (Morone saxatilis), tautog (Tautoga onitis), and bioavailable prey (forage fish and 703 invertebrates).

704

705 Fig. 2. (A) Sub-sampling locations in the dorsolateral muscle tissue of striped bass (Morone

706 saxatilis) and tautog (Tautoga onitis) (top and bottom fish image, respectively). (B) Relationship

707 between the total mercury concentration $\left(\mathrm{Hg} ; \mathrm{mg} \mathrm{Hg} \cdot \mathrm{kg}\right.$ wet weight $\left.{ }^{-1}\right)$ of a multiple biopsies

708 removed from the muscle tissue of striped bass $(n=18)$ and tautog $(n=14)$. Each muscle biopsy

709 was excised from the dorsal and lateral tissue along the anterior-posterior axis and represents the

710 mean ( \pm standard error) $\mathrm{Hg}$ concentration of the biopsy removed from the left and right side of

711 each fish.

712

713 Fig. 3. Total mercury concentration $\left(\mathrm{Hg} ; \mathrm{mg} \mathrm{Hg} \cdot \mathrm{kg}\right.$ wet weight $\left.{ }^{-1}\right)$ of the dorsal muscle tissue of

714 striped bass $(n=66)$ and tautog $(n=53)$ as a function of fish total length, $T L(\mathrm{~A})$ and age, $a(\mathrm{~B})$.

715 Exponential models were fit to the data and the equations are presented.

716

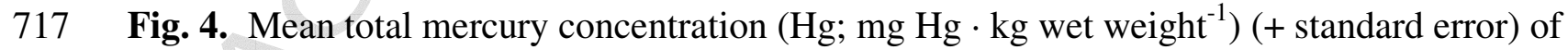
718 prey collected from the Narragansett Bay, i.e., "bioavailable prey”. Prey include bay anchovy 719 (Anchoa mitchilli; $n=39$ ), scup (Stenotomus chrysops; $n=56)$, green crab (Carcinus maenas; $n$ $720=110)$, river herring (Alosa spp.; $n=183)$, sand shrimp (Crangon septemspinosa; $n=241)$, 
721 back-finger mud crab (Panopeus herbstii; $n=15$ ), Atlantic menhaden (Brevoortia tyrannus; $n=$

722 32), and blue mussel (Mytilus edulis; $n=160$ ).

723

724 Fig. 5. Stable nitrogen $\left(\delta^{15} \mathrm{~N}\right)$ and carbon $\left(\delta^{13} \mathrm{C}\right)$ isotope signatures (mean \pm standard error) of

725 striped bass (Morone saxatilis), tautog (Tautoga onitis), and their prey ( $n=18-20$ per species).

726 Prey species include river herring (Alosa spp.), scup (Stenotomus chrysops), bay anchovy

727 (Anchoa mitchilli), Atlantic menhaden (Brevoortia tyrannus), green crab (Carcinus maenas),

728 sand shrimp (Crangon septemspinosa), and blue mussel (Mytilus edulis). Ovals represent

729 organisms that derive their carbon from pelagic or benthic sources, as determined by interspecies

$730 \quad \delta^{13} \mathrm{C}$ signatures.

731

732 Fig. 6. Relationship between total mercury concentration $\left(\mathrm{Hg} ; \mathrm{mg} \mathrm{Hg} \cdot \mathrm{kg}\right.$ wet weight $\left.{ }^{-1}\right)$ and

733 stable nitrogen $\left(\delta^{15} \mathrm{~N}\right)$ isotope signatures (mean \pm standard error) of striped bass (Morone

734 saxatilis), tautog (Tautoga onitis), and their prey $(n=18-20)$. Prey species include river herring

735 (Alosa spp.), scup (Stenotomus chrysops), bay anchovy (Anchoa mitchilli), Atlantic menhaden

736 (Brevoortia tyrannus), green crab (Carcinus maenas), sand shrimp (Crangon septemspinosa),

737 and blue mussel (Mytilus edulis). 


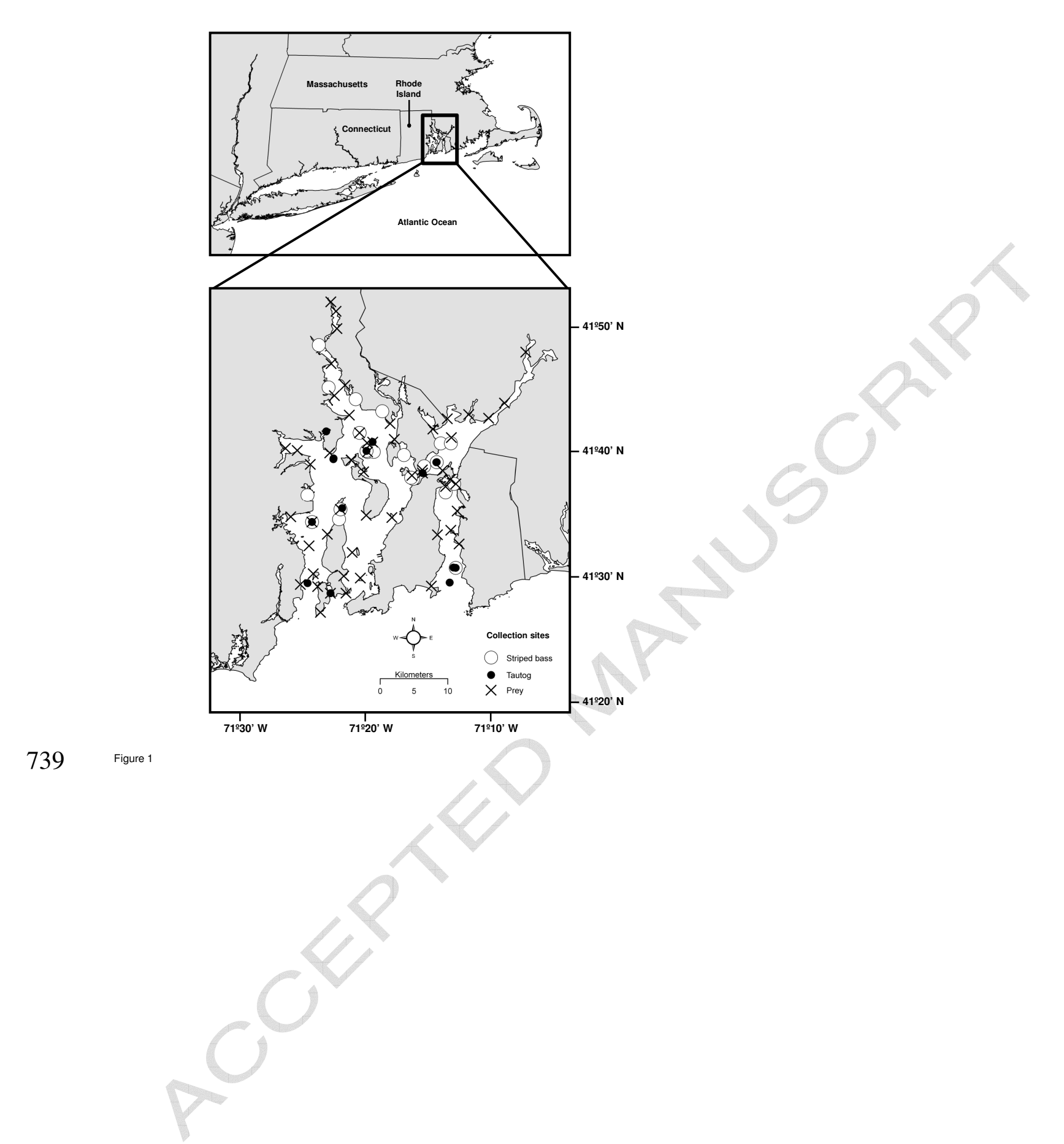


741 Comparison of total length, whole-body wet weight, muscle tissue water content, age, mercury levels [total mercury (Hg) and percent methylmercury (\%MeHg)], stable nitrogen $\left(\delta^{15} \mathrm{~N}\right)$ and carbon $\left(\delta^{13} \mathrm{C}\right)$ isotope signatures, and trophic level status of striped bass (Morone saxatilis) and tautog (Tautoga onitis) collected from the Narragansett Bay. Statistical summaries are from one-way analysis of variance models using species (striped bass and tautog) as a fixed factor. Sample sizes $(n)$, mean values $[ \pm$ standard error $(\mathrm{SE})]$, and ranges are also presented.

\begin{tabular}{|c|c|c|c|c|c|c|c|c|c|}
\hline \multirow[b]{2}{*}{ Parameter } & \multicolumn{3}{|c|}{ Striped bass } & \multicolumn{3}{|c|}{ Tautog } & \multirow[b]{2}{*}{$F$} & \multirow[b]{2}{*}{$d f$} & \multirow[b]{2}{*}{$p$} \\
\hline & $n$ & Mean $\pm \mathrm{SE}$ & Range & $n$ & Mean \pm SE & Range & & & \\
\hline Total length $(\mathrm{cm})^{\mathrm{a}}$ & 66 & $49.2 \pm 1.8$ & $26.2-102.0$ & 53 & $39.3 \pm 1.6$ & $10.7-56.4$ & 16.84 & 118 & $<0.0001$ \\
\hline Wet wt $(\mathrm{kg})^{\mathrm{a}}$ & 66 & $1.40 \pm 0.14$ & $0.18-6.82$ & 53 & $1.61 \pm 0.16$ & $0.10-3.88$ & 0.01 & 118 & 0.918 \\
\hline Water content $(\%)^{\mathrm{b}}$ & 42 & $77.2 \pm 0.7$ & $50.4-79.3$ & 45 & $78.6 \pm 0.5$ & $63.6-87.7$ & 3.44 & 86 & 0.067 \\
\hline $\operatorname{Age}(\mathrm{yr})^{\mathrm{a}, \mathrm{c}}$ & 66 & $4.3 \pm 0.2$ & $1.7-9.6$ & 53 & $11.3 \pm 0.6$ & $3.6-18.6$ & 168.18 & 118 & $<0.0001$ \\
\hline $\mathrm{Hg}\left(\mathrm{mg} \cdot \mathrm{kg} \text { wet } \mathrm{wt}^{-1}\right)^{\mathrm{a}}$ & 66 & $0.16 \pm 0.01$ & $0.03-0.45$ & 53 & $0.24 \pm 0.02$ & $0.03-0.58$ & 6.79 & 118 & $<0.05$ \\
\hline Age-normalized $\mathrm{Hg}^{\mathrm{a}, \mathrm{d}}$ & 66 & $0.038 \pm 0.003$ & $0.012-0.159$ & 53 & $0.020 \pm 0.001$ & $0.005-0.046$ & 39.47 & 118 & $<0.0001$ \\
\hline$\% \mathrm{MeHg}^{\mathrm{b}, \mathrm{e}}$ & 11 & $98.7 \pm 0.3$ & $96.3-99.6$ & 11 & $98.0 \pm 0.2$ & $96.8-98.9$ & 5.57 & 21 & $<0.05$ \\
\hline Recovered prey $\mathrm{Hg}^{\mathrm{a}, \mathrm{f}}$ & 54 & $0.060 \pm 0.005$ & $0.016-0.190$ & 50 & $0.053 \pm 0.005$ & $0.010-0.176$ & 1.91 & 103 & 0.170 \\
\hline$\delta^{15} \mathrm{~N}(\% o)$ & 20 & $17.66 \pm 0.27$ & $15.67-19.62$ & 18 & $15.76 \pm 0.12$ & $14.94-16.80$ & 38.92 & 37 & $<0.0001$ \\
\hline$\delta^{13} \mathrm{C}(\% \circ)$ & 20 & $-18.27 \pm 0.42$ & $-24.08--15.99$ & 18 & $-16.63 \pm 0.16$ & $-18.36--15.67$ & 12.21 & 37 & $<0.005$ \\
\hline Trophic level $^{g}$ & 20 & $4.07 \pm 0.08$ & $3.49-4.65$ & 18 & $3.51 \pm 0.03$ & $3.27-3.82$ & 39.07 & 37 & $<0.0001$ \\
\hline
\end{tabular}

$747 \quad{ }^{a}$ Data were $\log _{10}$-transformed prior to statistical analysis, but raw data values are presented in the table.

$748 \quad{ }^{\mathrm{b}}$ Data were arc-sin square-root transformed prior to statistical analysis, but raw data values are presented in the table.

$749{ }^{\mathrm{c}}$ Ages for individual fish were predicted from published age-size relationships (Hostetter and Munroe, 1993; Nelson et al., 2006).

$750 \quad{ }^{\mathrm{d}}$ Age-normalized $\mathrm{Hg}=\mathrm{Hg}\left(\mathrm{mg} \mathrm{Hg} \cdot \mathrm{kg}\right.$ tissue wet $\left.\mathrm{wt}^{-1}\right) /$ age $(\mathrm{yr})$.

$751{ }^{\mathrm{e}} \% \mathrm{MeHg}=\left[\mathrm{MeHg}\left(\mathrm{mg} \mathrm{MeHg} \cdot \mathrm{kg}\right.\right.$ tissue wet $\left.\mathrm{wt}^{-1}\right) /$ total $\mathrm{Hg}\left(\mathrm{mg} \mathrm{Hg} \cdot \mathrm{kg}\right.$ tissue wet $\left.\left.\mathrm{wt}^{-1}\right)\right] \times 100$.

$752{ }^{\mathrm{f}}$ Recovered prey $\mathrm{Hg}=\mathrm{Hg}\left(\mathrm{mg} \mathrm{Hg} \cdot \mathrm{kg}\right.$ wet $\left.\mathrm{wt}^{-1}\right)$ of food items removed from fish stomachs.

$753 \quad{ }^{\mathrm{g}}$ Trophic levels of individual target fish were calculated using Equation 2. 
755 Comparison of length, whole-body wet weight, whole-body water content, stable nitrogen $\left(\delta^{15} \mathrm{~N}\right)$ and carbon $\left(\delta^{13} \mathrm{C}\right)$ isotope signatures, and total mercury $(\mathrm{Hg})$ in 756 prey species collected from the Narragansett Bay. Sample sizes $(n)$, mean values ( \pm standard error), and ranges (in parentheses) are presented.

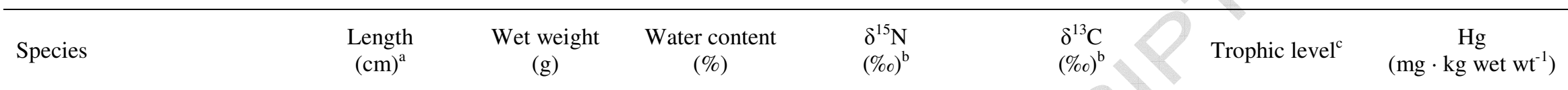

Division Teleostei

\begin{tabular}{|c|c|c|c|c|c|c|c|}
\hline $\begin{array}{l}\text { Atlantic menhaden } \\
(n=32)\end{array}$ & $\begin{array}{l}4.2 \pm 0.2 \\
(3.0-7.5)\end{array}$ & $\begin{array}{l}0.72 \pm 0.13 \\
(0.14-3.77)\end{array}$ & $\begin{array}{c}79.1 \pm 1.4 \\
(71.6-83.7)\end{array}$ & $\begin{array}{c}12.08 \pm 0.13 \\
(11.03-13.71)\end{array}$ & $\begin{array}{c}-18.77 \pm 0.11 \\
(-20.03--17.96)\end{array}$ & $\begin{array}{l}2.43 \pm 0.04 \\
(2.12-2.91)\end{array}$ & $\begin{array}{l}0.016 \pm 0.002 \\
(0.006-0.047)\end{array}$ \\
\hline $\begin{array}{l}\text { Bay Anchovy } \\
(n=39)\end{array}$ & $\begin{array}{l}7.3 \pm 0.1 \\
(5.3-8.2)\end{array}$ & $\begin{array}{l}2.72 \pm 0.12 \\
(0.98-4.01)\end{array}$ & $\begin{array}{c}77.2 \pm 0.5 \\
(74.2-79.1)\end{array}$ & $\begin{array}{c}14.39 \pm 0.13 \\
(13.72-15.74)\end{array}$ & $\begin{array}{c}-18.34 \pm 0.11 \\
(-19.23--16.99)\end{array}$ & $\begin{array}{l}3.11 \pm 0.04 \\
(2.91-3.51)\end{array}$ & $\begin{array}{l}0.035 \pm 0.001 \\
(0.029-0.055)\end{array}$ \\
\hline $\begin{array}{l}\text { River herring } \\
(n=183)\end{array}$ & $\begin{array}{c}6.2 \pm 0.2 \\
(2.9-11.2)\end{array}$ & $\begin{array}{c}2.53 \pm 0.16 \\
(0.08-11.15)\end{array}$ & $\begin{array}{c}78.1 \pm 0.3 \\
(71.0-83.7)\end{array}$ & $\begin{array}{c}13.42 \pm 0.19 \\
(12.31-15.47)\end{array}$ & $\begin{array}{c}-19.73 \pm 0.47 \\
(-25.67--17.04)\end{array}$ & $\begin{array}{l}2.82 \pm 0.06 \\
(2.50-3.43)\end{array}$ & $\begin{array}{l}0.027 \pm 0.001 \\
(0.008-0.188)\end{array}$ \\
\hline $\begin{array}{l}\text { Scup } \\
(n=56)\end{array}$ & $\begin{array}{l}10.3 \pm 0.5 \\
(2.8-15.3)\end{array}$ & $\begin{array}{l}23.75 \pm 2.24 \\
(0.32-71.21)\end{array}$ & $\begin{array}{c}75.6 \pm 0.3 \\
(72.6-81.8)\end{array}$ & $\begin{array}{c}14.91 \pm 0.22 \\
(12.88-16.33)\end{array}$ & $\begin{array}{c}-17.09 \pm 0.22 \\
(-18.12--13.61)\end{array}$ & $\begin{array}{l}3.26 \pm 0.07 \\
(2.66-3.68)\end{array}$ & $\begin{array}{l}0.033 \pm 0.002 \\
(0.015-0.066)\end{array}$ \\
\hline
\end{tabular}

Class Bivalvia

$\begin{array}{lccccccc}\text { Blue mussel } & 3.9 \pm 0.1 & 7.20 \pm 0.46 & 83.0 \pm 0.3 & 10.62 \pm 0.20 & -20.16 \pm 0.17 & 2.00 \pm 0.06 & 0.015 \pm 0.006 \\ (n=160)^{\mathrm{d}} & (1.8-8.2) & (1.07-38.66) & (72.1-38.66) & (9.15-92.7) & (-22.12--19.27) & (1.57-2.68) & (0.005-0.040)\end{array}$

Class Crustacea

$\begin{array}{lccccccc}\begin{array}{l}\text { Green crab } \\ (n=110)\end{array} & 4.2 \pm 0.2 & 24.21 \pm 2.62 & 73.4 \pm 1.0 & 12.90 \pm 0.20 & -15.13 \pm 0.25 & 2.67 \pm 0.06 & 0.032 \pm 0.003 \\ & (1.2-7.8) & (0.32-104.28) & (61.3-89.8) & (11.10-14.48) & (-17.15--13.25) & (11.10-14.48) & (0.006-0.156) \\ \begin{array}{l}\text { Mud crab } \\ (n=15)\end{array} & 1.7 \pm 0.2 & 2.58 \pm 0.61 & 65.1 \pm 3.3 & & - & - & 0.016 \pm 0.001 \\ & (0.9-2.6) & (0.20-7.37) & (54.5-82.8) & - & - & (0.006-0.025) \\ \begin{array}{l}\text { Sand shrimp } \\ (n=241)\end{array} & 3.8 \pm 0.1 & 0.49 \pm 0.02 & 78.5 \pm 0.4 & 13.52 \pm 0.23 & -15.67 \pm 0.55 & 2.85 \pm 0.07 & 0.020 \pm 0.001 \\ & (0.5-6.2) & (0.08-1.94) & (65.4-85.9) & (11.51-15.13) & (-21.09--12.47) & (2.26-3.33) & (0.006-0.123)\end{array}$

759 a Length measured as total length for fish and shrimp, carapace width for crabs, and shell height for mussels.

$760 \quad{ }^{\mathrm{b}}$ Sample size for stable nitrogen and carbon isotope analysis was 18-20 for all species. 
${ }^{\mathrm{c}}$ Trophic levels of individual prey species were calculated using Equation 2.

$762{ }^{\mathrm{d}}$ Mussel wet weight, water content, $\delta^{15} \mathrm{~N}, \delta^{13} \mathrm{C}$, and $\mathrm{Hg}$ were measured for soft tissue only (shell removed). 
Table 3

764 Stomach contents of striped bass (Morone saxatilis) and tautog (Tautoga onitis) collected from the Narragansett Bay. Values represent the percent of striped

765 bass or tautog stomachs that contained a given prey item.

\begin{tabular}{|c|c|c|c|}
\hline \multicolumn{2}{|c|}{ Recovered prey } & \multicolumn{2}{|c|}{ Target fish } \\
\hline Species & Common name & Striped bass & Tautog \\
\hline \multicolumn{4}{|l|}{ Division Teleostei } \\
\hline Alosa spp. & Herring & 2.5 & \\
\hline Anchoa mitchilli & Bay anchovy & 2.5 & 0 \\
\hline Brevoortia tyrannus & Atlantic menhaden & 1.3 & 0 \\
\hline Gobiosoma bosc & Naked goby & 2.5 & 0 \\
\hline Peprilus triacanthus & Butterfish & 1.3 & 0 \\
\hline Stenotomus chrysops & Scup & 1.3 & 0 \\
\hline Syngnathus fuscus & Northern pipefish & 1.3 & 0 \\
\hline \multicolumn{4}{|l|}{ Class Bivalvia } \\
\hline Mytilus edulis & Blue mussel & 0 & 19.1 \\
\hline \multicolumn{4}{|l|}{ Class Crustacea } \\
\hline Carcinus maenas & Green crab & 5.1 & 1.6 \\
\hline Crangon septemspinosa & Sand shrimp & 9.0 & 0 \\
\hline Panopeus herbstii & Black-finger mud crab & 0 & 4.8 \\
\hline - & Unidentified crab & 2.6 & 17.5 \\
\hline
\end{tabular}

Class Echinoidea 
Strongylocentrotus droebachiensis Green sea urchin

Class Gastropoda

Crepidula fornicata

-

Ulva lactuca

Atlantic slipper snai

Unidentified gastropod

3.2

1.3

Class Ulvophyceae

\begin{tabular}{lccc}
\multicolumn{1}{c}{ Ulva lactuca } & Sea lettuce & 1.3 & 0 \\
\hline Unidentified contents & 50.6 & 49.2 \\
Empty stomachs & 17.7 & 3.2 \\
\hline
\end{tabular}

767

768 
A
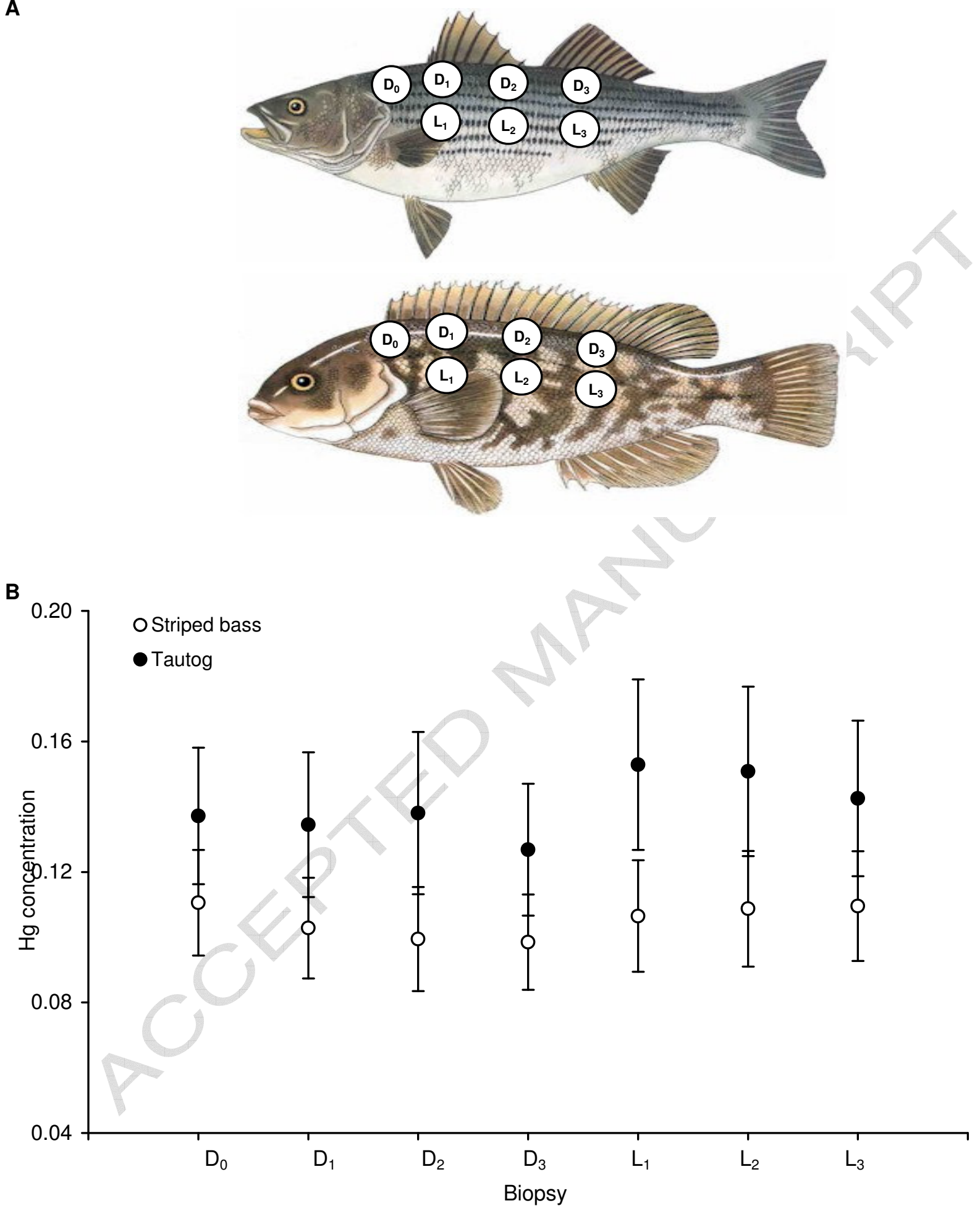

Figure 2 

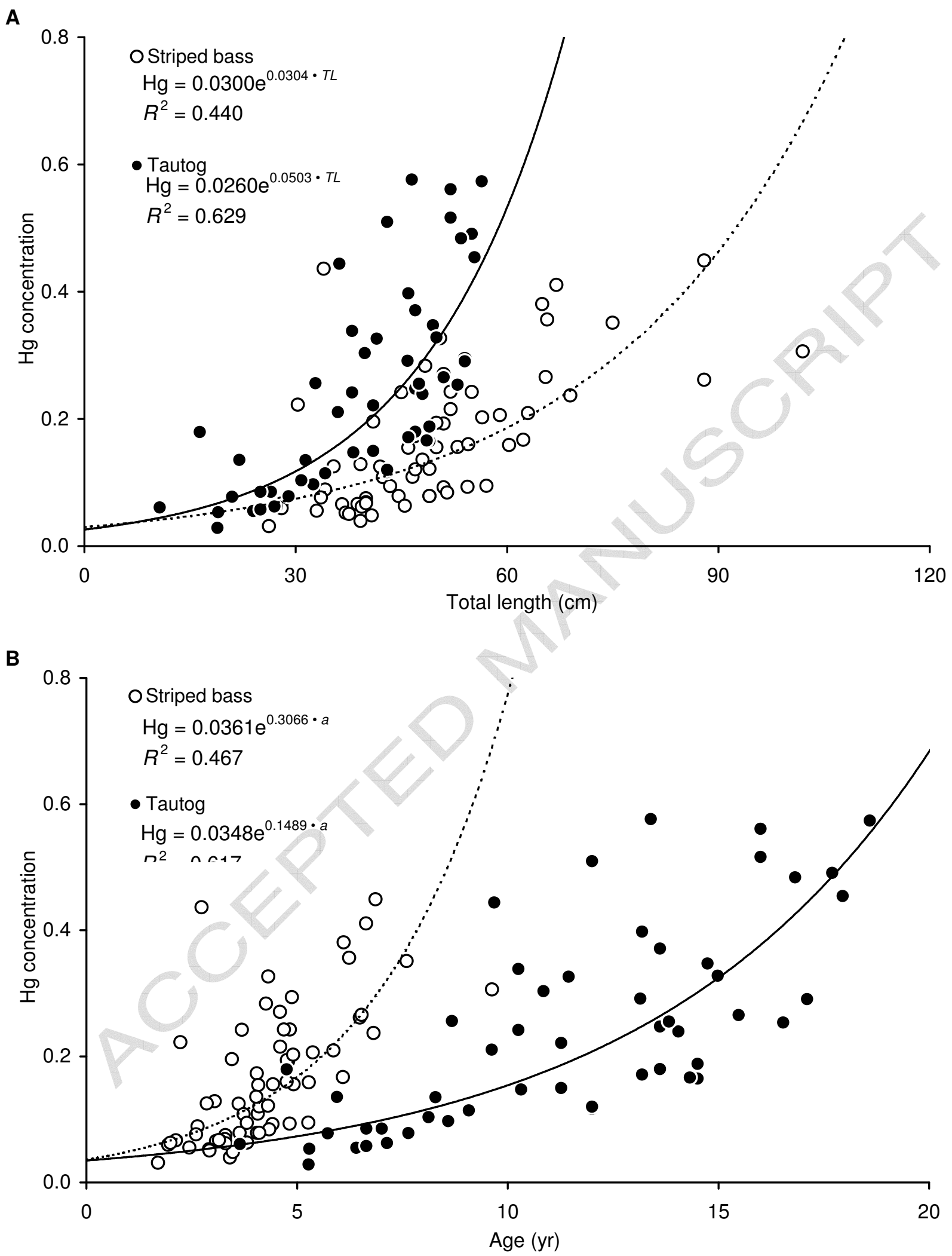

Figure 3 


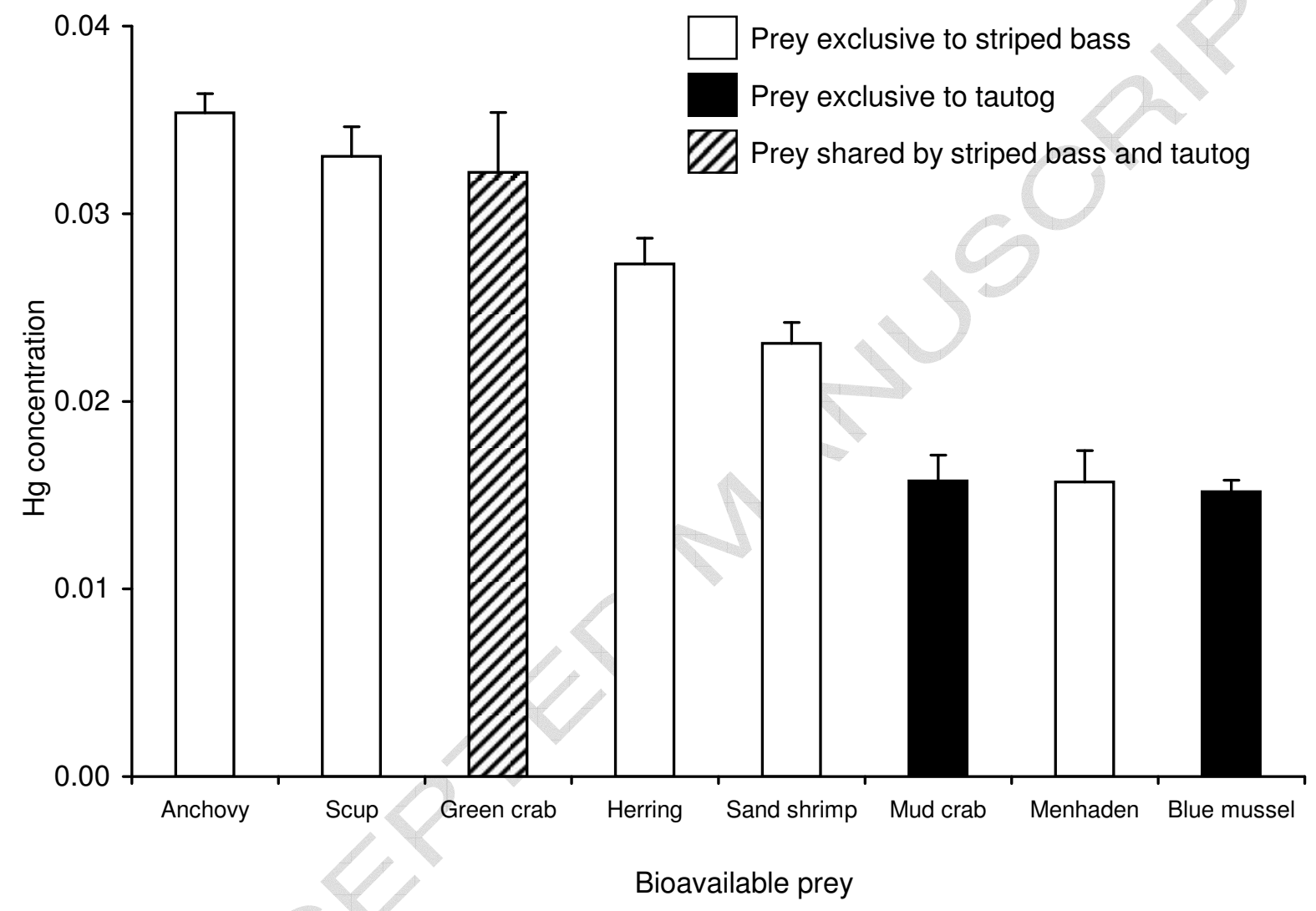

Figure 4 


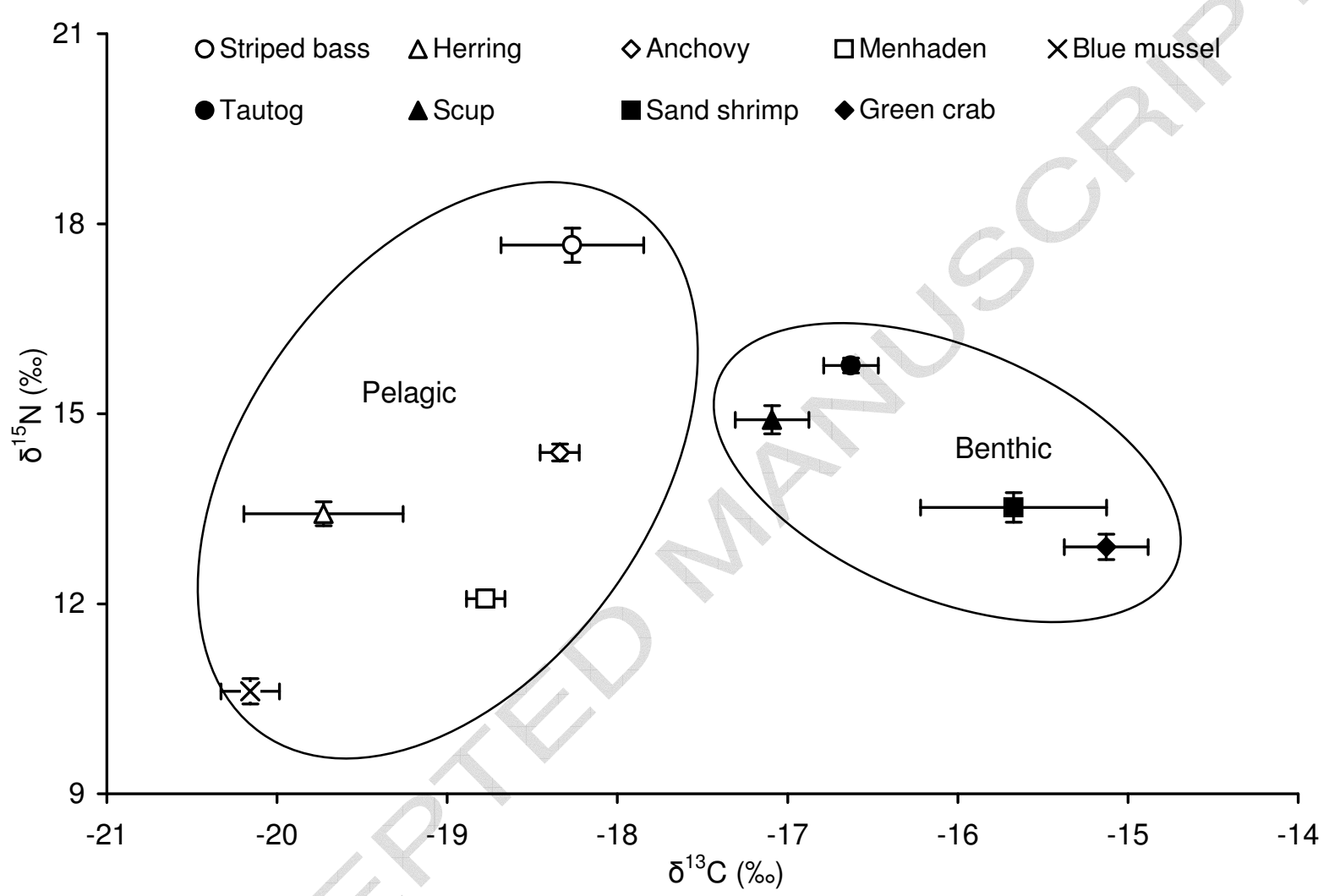

Figure 5 


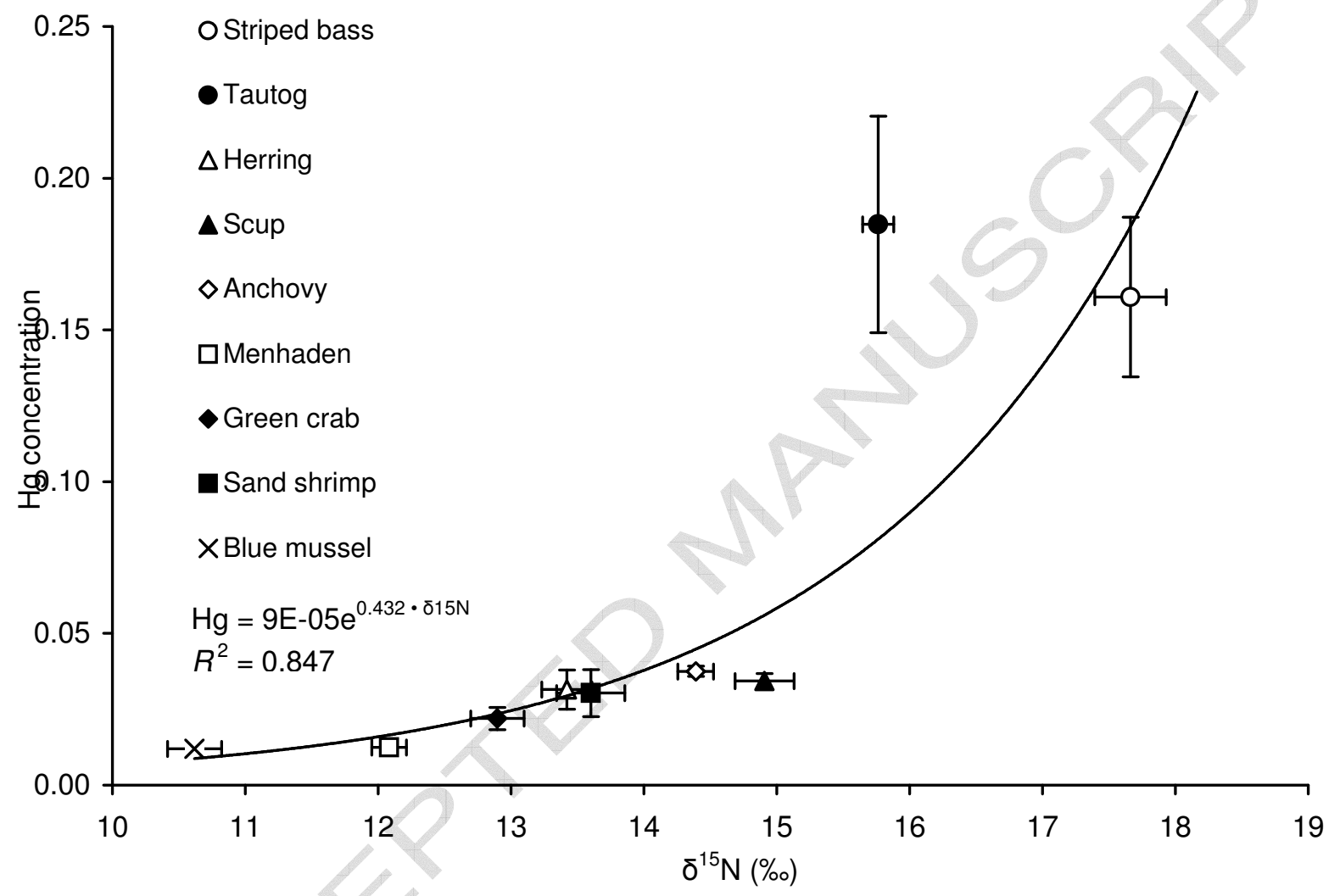

